\title{
Regulation of Neurotrophin Receptors during the Maturation of the Mammalian Visual System
}

\author{
Karen L. Allendoerfer ${ }^{1,2, a}$ Robert J. Cabelli, ${ }^{1}$ Enrique Escandón, ${ }^{3}$ David R. Kaplan, ${ }^{4}$ Karoly Nikolics, ${ }^{3}$ and Carla \\ J. Shatz' \\ 'Department of Molecular and Cell Biology, University of California at Berkeley, Berkeley, California 94720, \\ ${ }^{2}$ Neurosciences Program, Stanford University School of Medicine, Stanford, California 94305, ${ }^{3}$ Department of \\ Neuroscience, Genentech, Inc., South San Francisco, California 94080, and 4 Eukaryotic Signal Transduction Group, \\ MMCL, ABL-Basic Research Program, National Cancer Institute, Frederick Cancer Research and Development Center, \\ Frederick, Maryland 21702
}

Cell division, cell death, and remodeling of connections are major features of the construction of the mammalian CNS. We have begun to address the role of neurotrophins in these events through characterization of the expression of their receptors in the developing ferret visual system. By use of chemical cross-linking of iodinated neurotrophins, proteins corresponding to trkB, trk $C$, and $\mathrm{p} 75$ were identified as receptors for brain-derived neurotrophic factor (BDNF) and neurotrophin-3 (NT-3) throughout development. BDNF was also cross-linked to a truncated form of trkB that lacks the tyrosine kinase domain (trkB.T1) in retinal target tissues and in cortex. At the earliest developmental age examined (E24), the ratio of full-length to truncated trkB is $\gg 1$ in the retinal target tissues, LGN and superior colliculus. During the ensuing period of retinal ganglion cell death and segregation into eye-specific layers, the amount of truncated trkB increases markedly relative to full-length trkB. By $P 27$, truncated trkB is the predominant receptor for BDNF in the retinal target tissues and this pattern is maintained into adulthood. Within all subdivisions of visual cortex including the ventricular zone (VZ), intermediate zone (IZ), and cortical plate (CP), similar profiles of bands are observed. The developmental increase in abundance of truncated trkB relative to full-length occurs earliest in the $V Z$, with a major increase between $E 30$ and $P 3$. In the IZ, this shift to a predominance of truncated trkB occurs between P15 and P30, while in the $C P$ the shift is even further delayed, not occurring until after P30. Within each subdivision of cortex, the shift to a predominance of truncated trkB occurs at times that correlate

\footnotetext{
Received Mar. 17, 1993; revised July 26, 1993; accepted Oct. 4, 1993.

The first three authors (K.L.A., R.J.C., and E.E.) contributed equally to this study. This work was supported by NIH Grant EY02858 and the Alzheimer's and Related Disorders Association (C.J.S.), and NIH Grants EY06327 (R.J.C.) and NS07 158 (K.L.A.). We are very grateful to Drs. Luis Parada, Eric Shooter, and Andrew Welcher for their generous gifts of antibodies to neurotrophin receptors. We thank Dr. Shooter and Dr. Susan Meakin for providing unlabeled mouse NGF, and Dr. Grene Burton for RDNF and NT-3. In addition, we are grateful to Steven Ruzin (NSF Center of Plant Developmental Biology, UC Berkeley) and Sarah Townsend for assistance with densitometry.

Correspondence should be addressed to Dr. Carla J. Shatz, Department of Molecular and Cell Biology, University of California at Berkeley, Berkeley, CA 94720.

a Present address: Division of Biology, 216-76, California Institute of Technology, Pasadena, CA 91125.

Copyright (C 1994 Society for Neuroscience $0270-6474 / 94 / 141795-17 \$ 05.00 / 0$
}

with the onset of cell death and maturation of axonal connections. This study demonstrates that members of the trk family, previously identified in the CNS on the basis of mRNA transcripts, are present as receptors with specific binding affinities for BDNF and NT-3. Moreover, the correspondence between the developmental shift from full-length to truncated trkB and the critical periods for cell fate determination, cell death, and axonal remodeling suggests an important role for neurotrophic factors in the development of the visual system.

[Key words: brain-derived neurotrophic factor, NT-3, trkB, trkC, p75, retina, cortex, cross-linking]

The mammalian visual system is characterized by a precise pattern of connections, in which axons from neighboring retinal ganglion cells project to neighboring target neurons in the LGN of the thalamus and in the superior colliculus. In mammals with binocular vision, such as cats and ferrets, inputs from the two eyes are segregated into eye-specific layers in the LGN while projections from the LGN are in turn segregated into ocular dominance columns in primary visual cortex (Shatz, 1990). This remarkable specificity comes about, in part, through an initial overproduction of neurons and synapses, which are then eliminated during subsequent development (Cowan et al., 1984). The pruning of exuberant projections and the death of neurons during critical periods serve to eliminate cells and/or processes that have projected inappropriately. For example, retinal ganglion cell axons from one eye extend branches into the LGN layer appropriate to the other eye and then retract them during segregation (Sretavan and Shatz, 1984), and ganglion cells whose axons project to topographically inappropriate regions of the superior colliculus are preferentially eliminated by cell death (O'Leary et al., 1986). In the cat, nearly two-thirds of the ganglion cells that are initially born die between embryonic day 39 (E39) and E53 (Williams et al., 1986), during which time eyespecific layers form in the LGN (Shatz, 1983). In the ferret, another carnivore whose visual system develops similarly to that of the cat, the major phase of axonal segregation in the LGN occurs between postnatal day 3 (P3) and P14 (Linden et al., 1981), while the majority of retinal ganglion cell death appears to take place between birth and P6 (Henderson et al., 1988). The suggestion has been made that ganglion cell death is a consequence of competition for limiting amounts of trophic support (Cowan et al., 1984). 
Among those molcculcs that have becn shown to promote neuronal growth and survival are a structurally related family of small $(\sim 13 \mathrm{kDa})$, basic proteins, collectively known as the neurotrophins. Members of this family include NGF, the first discovered and prototypic neurotrophin (Thoenen and Barde, 1980), brain-derived neurotrophic factor (BDNF; Barde et al., 1982; Leibrock et al., 1989), neurotrophin 3 (NT-3; Ernfors et al., 1990; Hohn et al., 1990; Rosenthal et al., 1990; Maisonpierre et al., 1990), NT-4 (Halböök et al., 1991), and NT-5 (Berkemeier et al., 1991). Within the CNS, NGF is thought to provide trophic support for the basal forebrain cholinergic neurons (Dreyfus, 1989). There is also some evidence that neurotrophic factors may play a role in neuronal survival in the visual system. For example, BDNF supports the survival of cultured embryonic rat and chick retinal ganglion cells (Johnson et al., 1986; Rodriguez-Tébar et al., 1989) and NGF application in vivo can promote the survival of adult rat retinal ganglion cells following optic nerve axotomy (Carmignoto et al., 1989). While neurotrophins are best known as regulators of neuronal survival, evidence is accumulating that they may play roles in other processes in the nervous system including cell proliferation (Catteneo and McKay, 1990), differentiation (Anderson and Axel, 1986; Catteneo and McKay, 1990), synaptogenesis (Garofalo et al., 1992), and the regulation of axonal (Diamond et al., 1992) and dendritic (Purves et al., 1988; Cohen-Cory et al., 1991) arborization. For example, Maffei and co-workers (Domenici et al., 1991; Maffei et al., 1992) have shown that intracortical administration of large amounts of NGF may prevent both the loss of vision in the deprived eye following long-term eye closure in neonatal rats (Domenici et al., 1991a) and the accompanying shift in ocular dominance distribution also associated with monocular deprivation (Maffei et al., 1992). Both of these effects of monocular deprivation may be a consequence of altered axonal projections (Antonini and Stryker, 1993) and/or synaptic strength. Although the actual concentration of NGF achieved in these infusion experiments was not determined (leaving open the possibility that NGF at nonphysiological concentrations could have acted at receptors for other neurotrophins), these experiments do suggest a role for neurotrophins in visual system development. Indeed, mRNA for at lcast two mcmbers of the neurotrophin family, NGF and BDNF, is present in visual cortex, and the level of BDNF mRNA expression is increased by exposure to visual stimuli, both during development and in adulthood (Castrén et al., 1992).

Experiments in which iodinated NGF was chemically crosslinked to cell surface receptors identified a $75-80 \mathrm{kDa}$ protein as a possible receptor for NGF (Massague et al., 1982; Grob et al., 1983; Hosang and Shooter, 1985). This molecule was subsequently cloned (Chao et al., 1986; Radeke et al., 1987) and shown to confer low-affinity NGF binding when expressed in cells (Hempstead et al., 1989), hence its designation as the lowaffinity NGF receptor, or p75. All the members of the neurotrophin family identified thus far have similar affinities for $\mathrm{p} 75$ (Rodriguez-Tébar et al., 1990, 1992). In the visual system, p75 has been identified through 1-ethyl-3-(3-dimethylaminopropyl carbodiimide) $\mathrm{HCl}$ (EDAC)-mediated cross-linking in the retina (Escandón and Chao, 1990), and by immunohistochemistry in the retina (Schatteman et al., 1988; Yan and Johnson, 1988; Henderson, 1991), in the LGN and superior colliculus (Henderson, 1991; Rickman et al., 1991), and transiently in the subplate neurons of the developing cerebral cortex (Allendoerfer et al., 1990; Koh and Higgins, 1991; Wayne et al., 1991; Kordower and Mufson, 1992; Meinecke and Rakic, 1993). The subplate neurons, which are the earliest-generated neurons of the cerebral cortex, serve as temporary targets for thalamic afferents and are almost entirely eliminated by cell death shortly after those afferents grow into cortex. The expression of $\mathrm{p} 75$ in subplate neurons is downregulated just before the onset of cell death, suggesting a possible role for NGF or another neurotrophin in the survival and death of these cells (reviewed in Shatz et al., 1990; Allendoerfer and Shatz, 1994).

More recently, the $\operatorname{trk} A$ proto-oncogene has also been identified as a signal-transducing receptor for NGF (Kaplan et al., 1991; Klein et al., 1991a) and appears to be required for NGF action (Hempstead et al., 1991; Loeb et al., 1991). Human trkA encodes a 790 amino acid residue polypeptide that contains an extracellular amino-terminal domain, a single transmembrane segment, and a 357 amino acid residue cytoplasmic region containing a conserved tyrosine kinase domain (Martin-Zanca et al., 1989). Two other receptor tyrosine kinases bearing a high degree of homology to the trkA proto-oncogene have been identified (Klein et al., 1989; Lamballe et al., 1991 ; Middlemas et al., 1991). These proteins, trkB and trkC, were proposed to be receptors for BDNF and NT-3, respectively, although it has recently been suggested that trkB may also function as a receptor for NT-4 and NT-5 (Berkemeier et al., 1991; Klein et al., 199 lb, 1992; Lamballe et al., 1991; Soppet et al., 1991; Squinto et al., 1991). The $\operatorname{trk} B$ gene gives rise to multiple transcripts, including ones that encode the full-length protein and others that encode truncated forms that lack almost the entire cytoplasmic tyrosine kinase domain. The predominant truncated form (trkB.T1) contains a unique sequence of 11 amino acids at the carboxy terminus (Klein et al., 1990a; Middlemas et al., 1991).

Although a good deal is currently known about the roles of neurotrophic factors in cell survival in the PNS and in the adult brain, much less is known about the role of these factors in the developing CNS. In addition to the possible relevance of neurotrophic factors to issues of connectivity and cell survival, such as the development of eye-specific layers and ocular dominance columns, we sought to address whether neurotrophic factors might be involved in cell proliferation and cell fate determination. To determine the possible roles that neurotrophic factors might play in these processes, for which the ferret is a model species, it is necessary first to identify those neurotrophic factors and cognate receptors present during the critical stages of ferret visual system development. An additional advantage of the ferret as a model system is that the ferret's extended time course of development and its very premature birth relative to that of rodents permit a more detailed resolution of early developmental steps. To detect the presence of specific neurotrophin receptors, we chose as a method the cross-linking of iodinated neurotrophic factors to their receptors. Within the developing CNS, virtually all the information available regarding trk receptors is in the form of in situ or Northern analysis (Klein et al., 1989, 1990b; Lamballe et al., 1991; Ernfors et al., 1992). Whereas neither immunoblot nor mRNA analysis addresses the functionality of the identified molecules, cross-linking is dependent on ligand-receptor binding, the specificity of which is easily determined. Moreover, information on the molecular identity of cross-linked receptors can also be obtained. In view of the fact that very little mRNA for trkA (Martin-Zanca et al., 1990) has been observed within the CNS [in contrast to trkB and trkC mRNA (Klein et al., 1989, 1990b; Lamballe et al., 1991)], we focused our analysis on the identification of BDNF and NT-3 


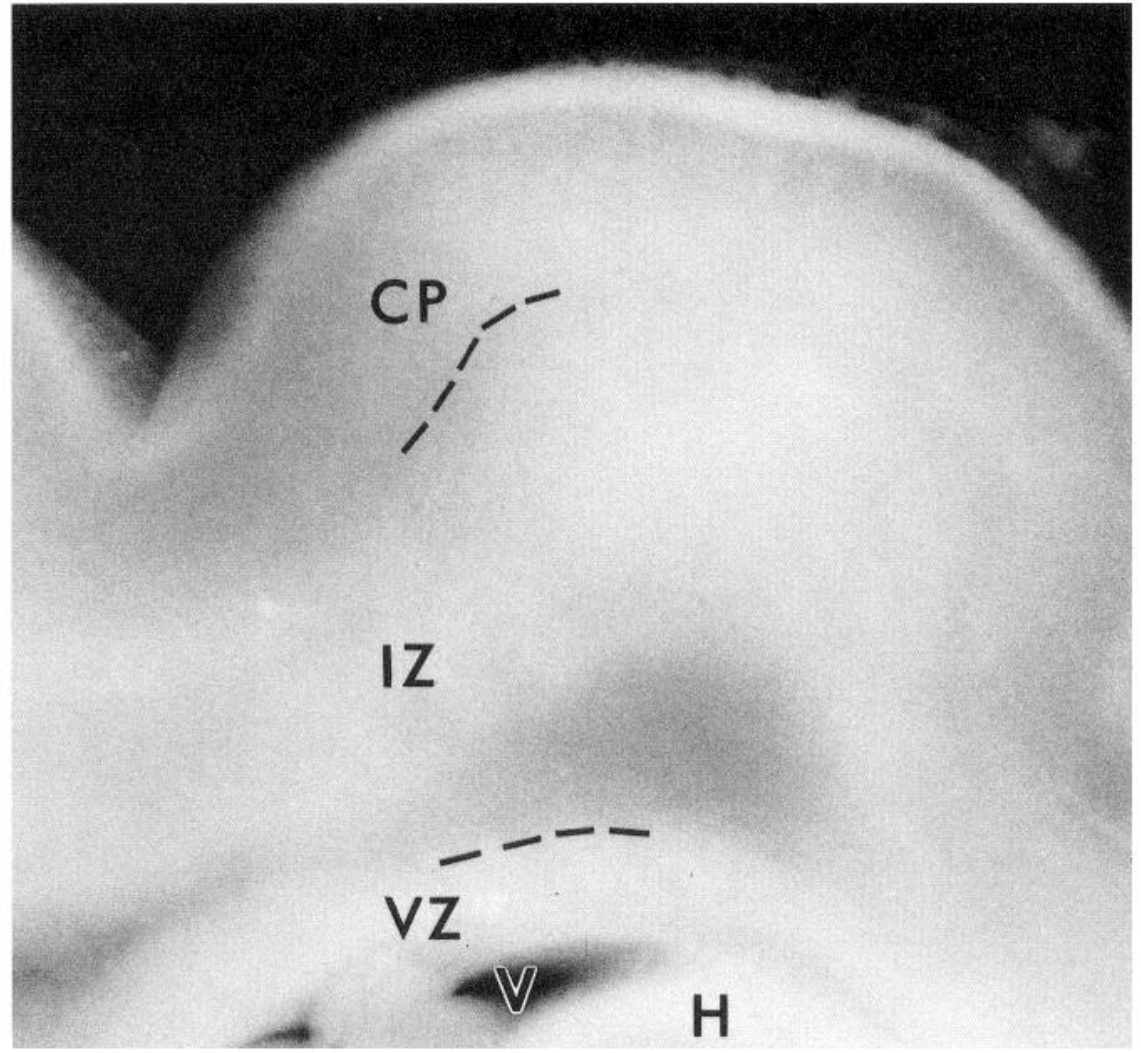

Figure 1. Subdissection of fresh cortical slices into ventricular zone, intermediate zone, and cortical plate. A 500$\mu \mathrm{m}$-thick horizontal slice was cut by vibratome from the visual cortex of a P15 ferret. Cuts were made as shown along the broken lines to divide the cortex into ventricular zone $(V Z)$, intermediate zone $(I Z)$, and cortical plate $(C P)$. $H$, hippocampus; $V$, ventricle. receptors. We have carried out a study of the presence of these receptors in the developing ferret visual system using as a method of detection the formation of cross-links between iodinated neurotrophic factors and cell surface receptors on preparations of freshly dissociated tissue.

\section{Materials and Methods}

Materials. Recombinant human BDNF and NT-3 were prepared as described by Rosenthal et al. (1990, 1991), and generously provided by Dr. Louis E. Burton (Genentech). Mouse NGF ( $\beta$-subunit) used as unlabeled competitor was a gift from Drs. Susan Meakin and Eric Shooter (Stanford University, Stanford, CA) or was purchased from Bioproducts for Science, Inc. 1-Ethyl-3-(3-dimethylaminopropyl carbodiimide) $\mathrm{HCl}$ (EDAC) was obtained from Pierce Chemical Co. (no. $22980 \mathrm{G}$ ). The rabbit polyclonal antibodies prepared against the 14 carboxy-terminal amino acids of human trkA (pan-trk), against amino acids 488-507 (FMTLGGSSLSPTEGKGSGLQ) of human trkA (anti-TrkAin), against amino acids 482-501 (HISNGSNTPSSSEGGPDAVI) of rat trkB (antiTrkBin), against amino acids 487-502 (SNTPSSSEGGPDAVII) of rat trkB (anti-TrkBjux), against amino acids 76-96 (QKRLEIINEDDVEAYVGLKNL) of rat trkB (anti-TrkBout), and against amino acids 88-108 (WRGLHTLNAVDMELYTGLQKL) of rat trkC (anti-TrkCout) were kindly provided by Dr. David Kaplan (NCI-FCRDC, Frederick, MD). The rabbit polyclonal antibody prepared against the 11 amino acids corresponding to the alternately spliced exon in trkB.T1 mRNA was kindly provided by Dr. Luis Parada (NCI-FCRDC, Frederick, MD). The rabbit polyclonal antibody prepared against a trpE fusion protein containing the extracellular domain of rat trkC (anti-trkCex) was obtained from Dr. Andrew Welcher (AMGEN, Inc., Thousand Oaks, CA). The affinity-purified rabbit polyclonal antisera directed against residues 258-276 of rat p75 was a gift of Drs. Eric Shooter (Stanford) and David Shelton (Genentech).

Preparation of iodinated neurotrophins. Iodinated BDNF and NT-3 were prepared using the Enzymobead reagent (Bio-Rad), as described in Escandón et al. (1993), to a specific activity of between 50,000$150,000 \mathrm{cpm} / \mathrm{ng}$.
Tissue dissection and preparation. Timed-pregnant sable ferrets were obtained from Marshall Farms (North Rose, NY). Postnatal animals were given a lethal dose of Nembutal $(50 \mathrm{mg} / \mathrm{kg}$; for fetal experiments, the pregnant jill was overdosed and the fetuses removed), and eyes were removed and retinas dissected in room temperature, oxygenated, HEPESbuffered Ames medium (Sigma). The brain was exposed, and the meninges and choroid plexus were removed and brain tissues dissected in chilled $\left(4^{\circ} \mathrm{C}\right)$ Dulbecco's phosphate-buffered saline (137 mM NaCl, 9.6 $\mathrm{mM} \mathrm{Na}_{2} \mathrm{HPO}_{4} \cdot 7 \mathrm{H}_{2} \mathrm{O}, 2.7 \mathrm{~mm} \mathrm{KCl}, 1.5 \mathrm{~mm} \mathrm{KH}_{2} \mathrm{PO}_{4}$ ) containing $5 \mathrm{mg} /$ $\mathrm{ml}$ glucose (PBS-glucose). Hippocampus and striatum were carefully separated from the cortex, and approximately the posterior third of cortex, containing the visual cortical area in ferrets (Law et al., 1988), was removed. In ferrets P3 and older, the superior colliculus and LGN are distinct morphological structures that can be identified. Dissection of the superior colliculus was terminated above the aqueduct of sylvius, to ensure that no substantia nigra tissue was included in these preparations. In fetal experiments (E24, E30, E37), structural boundaries were indistinct; therefore, the entire dorsolateral thalamus, containing the LGN anlagen, was dissected; the entire dorsal midbrain, containing the future superior and inferior colliculi, was also used. To subdivide the cortex into ventricular zone, intermediate zone, and cortical plate, brains were first cut into $500-\mu \mathrm{m}$-thick coronal or horizontal slices, with either a brain slicer (as described in Katz, 1987) for E30, or a vibratome for P3 and older. Fresh slices were then subdissected in cold PBS-glucose under a dissecting microscope as shown in Figure 1. At E30, no distinction between the intermediate zone and cortical plate was visible; therefore, the slices were simply divided into ventricular zone and cortical plate at this age. Between 2 (P50 or adult) and 10 (E30) animals or fetuses were used per experiment. The complete dissection of the tissues used in a given experiment took no more than $2 \mathrm{hr}$. In the developmental time series for BDNF and NT-3 cross-linking, all experiments were carried out independently at least two times, with the exception of the prenatal time points, where only one experiment at each age was performed.

After dissection, tissues were dissociated mechanically by repeated passage through an 18 gauge needle. Retinal tissue was washed two times with room temperature PBS-glucose to remove primary amines in the Ames medium that might deactivate the cross-linking reagent. 
Cortex

Figure 2. Cross-linking of iodinated BDNF and NT-3 in cortex and LGN from P10 ferrets. Cross-linking reactions were carried out on tissue suspensions prepared from cortex and LGN as described in Materials and Methods. Iodinated neurotrophins were incubated at a concentration of $1 \mathrm{nM}$ (based on a dimer), and unlabeled competitors were present as indicated at concentrations of $150 \mathrm{~nm}$. Detergent extracts of the cross-linking reactions were analyzed by SDS-PAGE followed by autoradiography. The open and stippled arrows point to BDNF cross-linked bands. The solid and stippled arrows point to NT-3 cross-linked bands. Molecular weight markers are shown to the right.

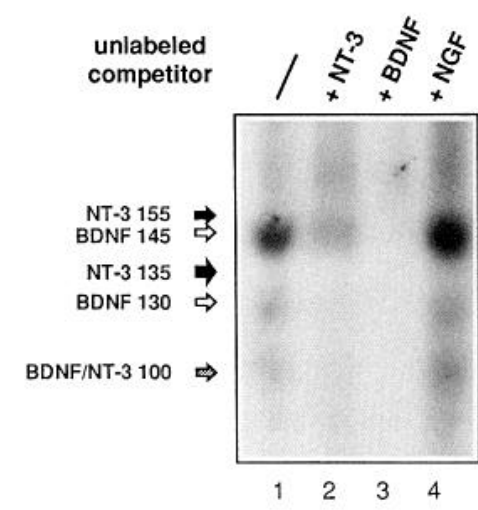

iodinated factor

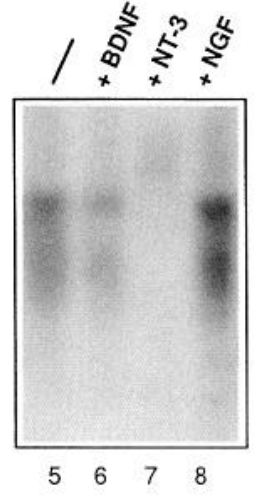

NT-3

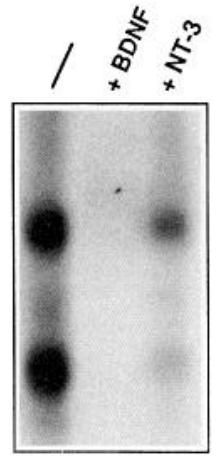

$9 \quad 10 \quad 11$

BDNF

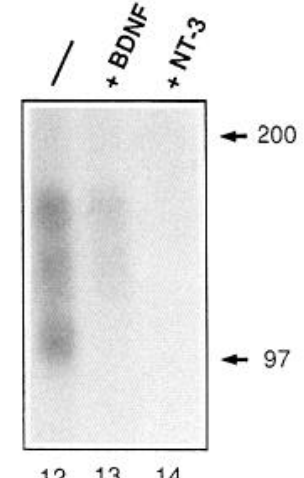

$\begin{array}{lll}12 & 13 & 14\end{array}$

NT-3
The other tissues were sedimented and resuspended in room temperature PBS-glucose.

Cross-linking reaction and analysis. Cross-linking reactions were carried out as described in Escandon and Chao (1990) with some modifications. Suspensions of triturated cells in PBS-glucose were incubated with constant mixing in a volume of from 0.25 to $1 \mathrm{ml}$, depending on the amount of tissue available. Protein concentrations of tissue suspensions generally varied from 0.2 to $1.2 \mathrm{mg} / \mathrm{ml}$, although occasionally in cortical preparations concentrations were as high as $2-4 \mathrm{mg} / \mathrm{ml}$. We determined that a 10 -fold difference in protein concentration, from 0.1 to $1 \mathrm{mg} / \mathrm{ml}$, had no effect on the relative proportion(s) of different crosslinked species. Incubations were initiated by addition of unlabeled followed by iodinated neurotrophic factors. Steady-state binding was achieved by incubation for $1 \mathrm{hr}$ at $4^{\circ} \mathrm{C}$, except for retinal preparations, which were incubated at room temperature to preserve the integrity of the retinal ganglion cells, which have been shown to be sensitive to chilling (Barres et al., 1988). Iodinated neurotrophic factors were present at $1 \mathrm{~nm}$ (based on a dimer), while unlabeled neurotrophic factors were added at $150 \mathrm{~nm}$ unless otherwise noted. At the conclusion of the binding reaction, freshly prepared EDAC $(0.2 \mathrm{M}$ in water) was added to a final concentration of $4 \mathrm{~mm}$ and the incubation was continued for an additional $30 \mathrm{~min}$ at room temperature. Cross-linking was terminated by a series of three washes with $1 \mathrm{ml}$ of cold PBS containing $50 \mathrm{~mm}$ lysine and $1 \mathrm{~mm}$ phenylmethylsulfonyl fluoride (PMSF) for each sample. Pellets were extracted with PBS supplemented with $1 \%$ Triton X-100, 4.2 $\mathrm{mM} \mathrm{MgCl}_{2}$, and $100 \mu \mathrm{g} / \mathrm{ml} \mathrm{DNase} \mathrm{I} \mathrm{(Sigma)} \mathrm{for} \mathrm{at} \mathrm{least} 30 \mathrm{~min}$ at room temperature with periodic vortexing. Extractions were sedimented for $5 \mathrm{~min}$ at $12,000 \times g$ and the supernatants were removed for analysis by SDS-PAGE or immunoprecipitation followed by SDS-PAGE.

Immunoprecipitation. Cross-linking supernatants $(25-50 \mu \mathrm{l})$ were brought to a final concentration of $20 \mathrm{~mm}$ Tris- $\mathrm{HCl} \mathrm{pH} 7.5,150 \mathrm{~mm}$ $\mathrm{NaCl}, 1 \%$ Triton $\mathrm{X}-100,0.1 \%$ sodium dodecyl sulfate, $1 \%$ sodium deoxycholate, $5 \mathrm{~mm}$ ethylene diamine tetraacetic acid (EDTA), $1 \mathrm{~mm}$ PMSF (diluted from a $0.5 \mathrm{M}$ stock in methanol at $-20^{\circ} \mathrm{C}$ ), $1 \mu \mathrm{g} / \mathrm{ml}$ leupeptin, and $10 \mu \mathrm{g} / \mathrm{ml}$ aprotinin in a volume of $200 \mu \mathrm{l}$ for immunoprecipitation with anti-truncated trkB, anti-p75, and pan-trk. For immunoprecipitation with antibodies against trkA, trkB, or trkC, supernatants were brought to a final concentration of $20 \mathrm{~mm}$ Tris- $\mathrm{HCl}$ pH $8.0,150 \mathrm{~mm} \mathrm{NaCl}, 1 \%$ Triton X-100, and $10 \%$ glycerol, with PMSF, leupeptin, and aprotinin as before (lysis buffer). Antibodies were added as indicated in the text and supernatants were incubated overnight at $4^{\circ} \mathrm{C}$ with constant rotation. Fifty microliters of a $50 \%$ slurry of protein A-Sepharose 4B-CL (Pharmacia-LKB) in the appropriate buffer were added to each tube and incubated for an additional $1-2 \mathrm{hr}$ with mixing at $4^{\circ} \mathrm{C}$. Immunoprecipitates were pelleted and washed four times with $0.75 \mathrm{ml}$ of cold buffer. Pellets were resuspended in sample buffer, boiled, and subjected to SDS-PAGE.

For deglycosylation, washed immunoprecipitates were resuspended in $0.5 \%$ SDS and $1 \% \beta$-mercaptoethanol and boiled for $10 \mathrm{~min}$. Following sedimentation, supernatants were brought to $1 \%$ in NP-40 and incubated with recombinant PNGase F (New England Biolabs) for $1 \mathrm{hr}$ at $37^{\circ} \mathrm{C}$. Deglycosylated samples were diluted into lysis buffer and subjected to immunoprecipitation analysis as described above.

Gel electrophoresis, autoradiography, and densitometry. Cross-linking supernatants and immunoprecipitates were boiled for $5 \mathrm{~min}$ in SDS sample buffer and subjected to electrophoresis in $6 \%$ polyacrylamide, $0.5 \%$ bisacrylamide SDS gels. Gels were dried and exposed to XAR-5 $\mathrm{x}$-ray film for various periods of time at $-80^{\circ} \mathrm{C}$ with an intensifying screen. Autoradiograms for the LGN, superior colliculus, and cortex experiments were scanned on a Bio-Rad scanning video densitometer (model 620) in transmittance mode and peak areas were calculated using the 1D ANALYST II software, version 3.10 (Bio-Rad). Autoradiograms for the cortical subdissection experiments were analyzed by video densitometry using a Javelin Ultrachip video camera and NIH IMAGE software, version 1.44. For reasons discussed in Results, it was not possible to compare absolute amounts of labeled receptor between lanes, even within the same experiment. Instead, ratios of trkB to truncated trkB were calculated by dividing the peak area of the $145 \mathrm{kDa}$ band by the peak area of the $100 \mathrm{kDa}$ band. To ensure that there was no contribution of cross-linked p75 to the signal present in the $100 \mathrm{kDa}$ band, we performed the quantitation on those lanes in which excess cold NGF had been added as a competitor. In some cases, the addition of cold NGF also resulted in a general reduction in background (e.g., see Fig. $7 A$ ). In all cases, quantitation was carried out with several different exposures of each gel. A standard curve was used to ensure that the quantitated bands fell within the linear response range of the film.

\section{Results}

Iodinated BDNF and NT-3 were chemically cross-linked to their receptors using EDAC in preparations of mechanically dissociated tissue from ferret retina, LGN, superior colliculus, and cortex, at developmental ages ranging from E24 to adult. The pattern of neurotrophin cross-linking was examined at ages spanning this range of visual system development, while the specificity of cross-linking and identity of cross-linked complexes were determined at a few selected ages.

\section{Specificity of cross-linking reactions}

In all tissues and at all ages examined, we observed the specific cross-linking of iodinated BDNF and NT-3 to discrete sets of proteins. These patterns are shown in Figures 2 and 3, which contain data from experiments performed at P10 and P3, respectively. Labeled neurotrophic factors were present at a concentration of $1 \mathrm{nM}$ during the binding and cross-linking reactions to insure saturation of high-affinity receptors and substantial occupancy of low-affinity receptors (Hosang and Shooter, 1985).

As shown in Figure 2, cross-linking of iodinated BDNF in 
cortex and LGN revealed three bands: an upper band of $\sim 145$ $\mathrm{kDa}$, a middle band at $\sim 130 \mathrm{kDa}$, and a lower band at $\sim 100$ $\mathrm{kDa}$. In order to examine the specificity of BDNF for these bands, we first included a 150-fold excess of unlabeled BDNF during the binding and cross-linking reactions. This completely prevented the generation of specific iodinated cross-linked complexes (compare lanes 1 and 3, and lanes 9 and 10 in Fig. 2). These bands were highly specific for BDNF relative to NGF, since inclusion of excess unlabeled NGF during the reactions did not affect the labeling of these bands (Fig. 2, lanes 1, 4; Fig. $3 A$, lanes 3,4$)$. Addition of excess NT-3 significantly reduced the labeling of the lower band while also partially competing the labeling of the two larger species (Fig. 2, lanes 2, 11).

The cross-linking of iodinated NT-3 generated a distinct upper band of $\sim 155 \mathrm{kDa}$, a diffuse middle band of $\sim 135 \mathrm{kDa}$, and, in the LGN, a lower band of $\sim 100 \mathrm{kDa}$ (Fig. 2, lanes 5$8,12-14)$. Labeling of the two larger bands was unaffected by inclusion of an excess of NGF, partially reduced by excess BDNF, and was completely blocked by excess unlabeled NT-3. However, the $100 \mathrm{kDa}$ NT-3 cross-linked band was fully competed by the presence of excess BDNF or NT-3 (e.g., Fig. 2, lanes 13, 14) and was partially competed by inclusion of excess NGF (data not shown, but see Fig. 10). The pattern observed for crosslinking of iodinated BDNF and NT-3 in the superior colliculus, the other retinal target analyzed, was qualitatively similar to that in the LGN (see Figs. $5 A ; 7 B, C ; 10 A, B$; data not shown).

In retina, the cross-linking of iodinated BDNF resulted in three consistently labeled bands of 145,130 , and $100 \mathrm{kDa}$. The additional $170 \mathrm{kDa}$ band shown in Figure $3 A$, lanes 7 and 8 , was not observed reproducibly, could not be competed by an excess of any neurotrophin, and thus is unlikely to represent a specific BDNF receptor. While the sensitivity of labeling of the 145 and $130 \mathrm{kDa}$ bands to competition by excess neurotrophic factors was similar to that observed in the LGN and cortex (see Fig. $3 A$, lane 8 ; data not shown), the labeling of the $100 \mathrm{kDa}$ band was, in contrast, completely abolished by inclusion of an excess of NGF (lane 8). The primary product of cross-linking of iodinated NT-3 in retina was a $100 \mathrm{kDa}$ band, although a faint signal corresponding to $155 \mathrm{kDa}$ and $130 \mathrm{kDa}$ bands can be seen (see Fig. 3A, lane 9). Again, excess NGF was able to compete completely for the labeling of this $100 \mathrm{kDa}$ band (see Figs. $5 A, 10 D)$.

These observations indicate that the binding of BDNF and NT-3 to receptors in visual system structures is highly specific. In all tissues, $145 \mathrm{kDa}$ and $130 \mathrm{kDa}$ bands were selectively labeled with BDNF, and 155 and $135 \mathrm{kDa}$ bands were selectively labeled with NT-3. However, in keeping with observations in transfected cell lines (Klein et al., 1991b; Soppet et al., 1991; Squinto et al., 1991), NT-3 and BDNF were able to compete partially for each other's binding to these receptors. The $100 \mathrm{kDa}$ band in cortex and retinal target tissues, while completely resistant to competition with excess cold NGF, was even less selective for BDNF versus NT-3. The $100 \mathrm{kDa}$ band in retina was nonselective with respect to all three neurotrophins.

\section{Identity of cross-linked bands}

In order to determine the identity of these BDNF and NT-3 binding proteins, we performed immunoprecipitation analysis with antibodies to different forms of known neurotrophic factor receptors. The antibodies used in this study were as follows (Fig. 4): pan-trk antibody (Kaplan et al., 1991), directed against the 14 carboxy-terminal amino acids of trkA protein and which
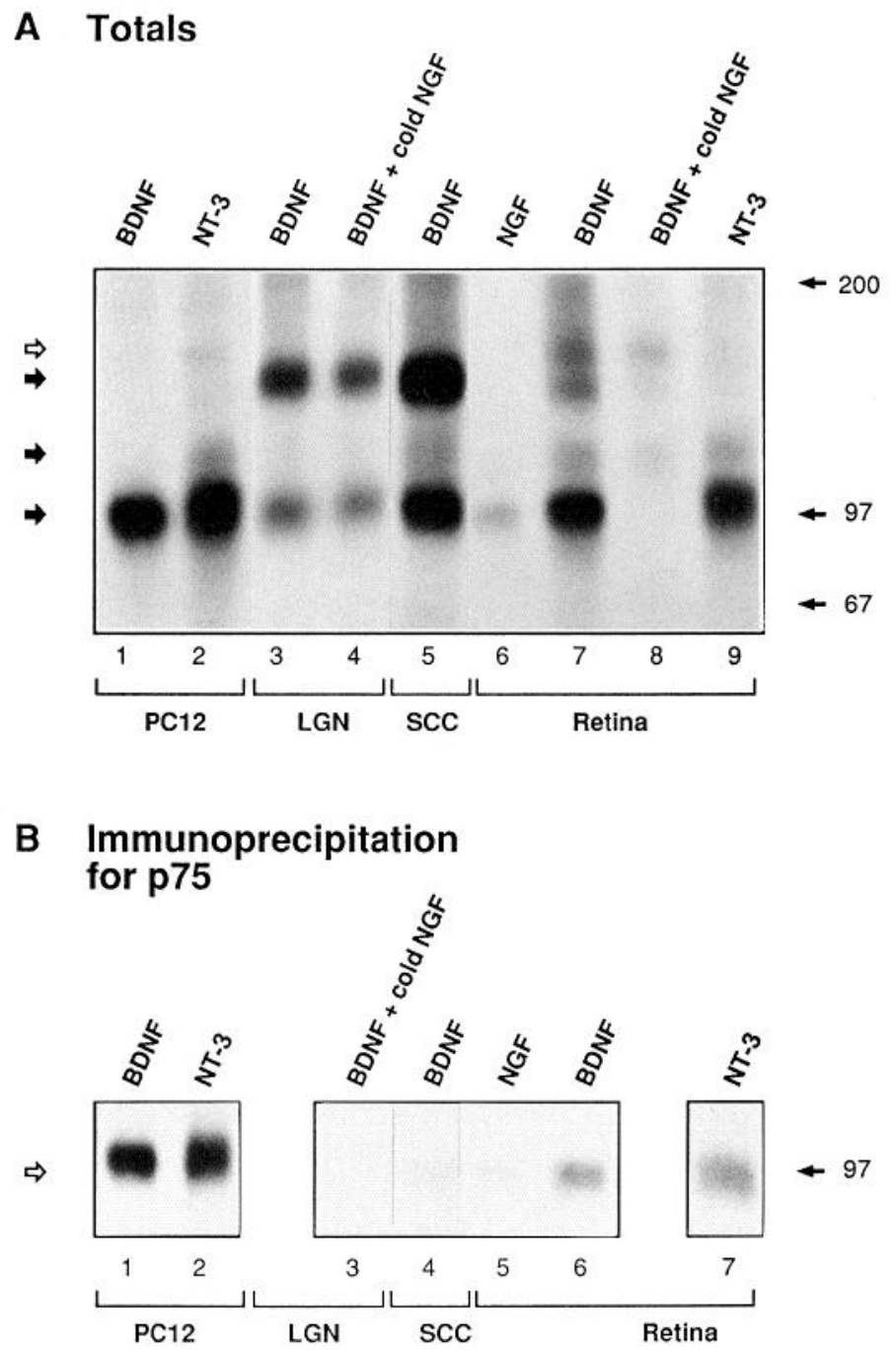

Figure 3. Comparison of the $100 \mathrm{kDa}$ bands in retina and retinal target tissues at $\mathrm{P} 3$. $A$, Cross-linking reactions were carried out in $\mathrm{PC} 12$ cell suspensions and tissue suspensions prepared from LGN, superior colliculus, and retina. (The iodinated NGF used in this experiment had a specific activity significantly less than that of the BDNF and NT-3.) The open arrow points to the nonspecific BDNF-labeled band occasionally seen in retina. The solid arrows point to the $145 \mathrm{kDa}$ and 130 $\mathrm{kDa}$ bands labeled by BDNF and the $100 \mathrm{kDa}$ bands labeled by BDNF and NT-3. Lanes 1 and 2 were exposed to $\mathrm{x}$-ray film for $4 \mathrm{~d}$, while lanes $3-9$ are 10 d exposures. $B$, Aliquots of certain of the samples shown in $A$ were subjected to immunoprecipitation with anti-p 75 ( $2.5 \mu$ l per tube $)$ as described in Materials and Methods. The open arrow points to the immunoprecipitated $100 \mathrm{kDa}$ complexes of p75 with BDNF or NT-3. Molecular weight markers are shown to the right. All lanes are 2 week exposures.

accordingly recognizes trkA, trkB, and trkC proteins; anti-trkAin, directed against residues 488-507 in the intracellular domain of human trkA; anti-trkBin and anti-trkBjux, directed against residues 482-501 and 487-502, respectively, in the intracellular domain of rat trkB; anti-truncated trkB (Soppet et al., 1991), directed against the alternately spliced cytoplasmic domain specific for trkB.T1 (Klein et al., 1990a; Middlemas et al., 1991); anti-trkBout (Kaplan et al., 1993), directed against residues 7696 in the extracellular domain of rat trkB; anti-trkCex, directed against a trpE fusion protein containing the extracellular domain of rat trkC; anti-trkCout, directed against residues 88-108 in the extracellular domain of rat trkC; and anti-p75, directed 


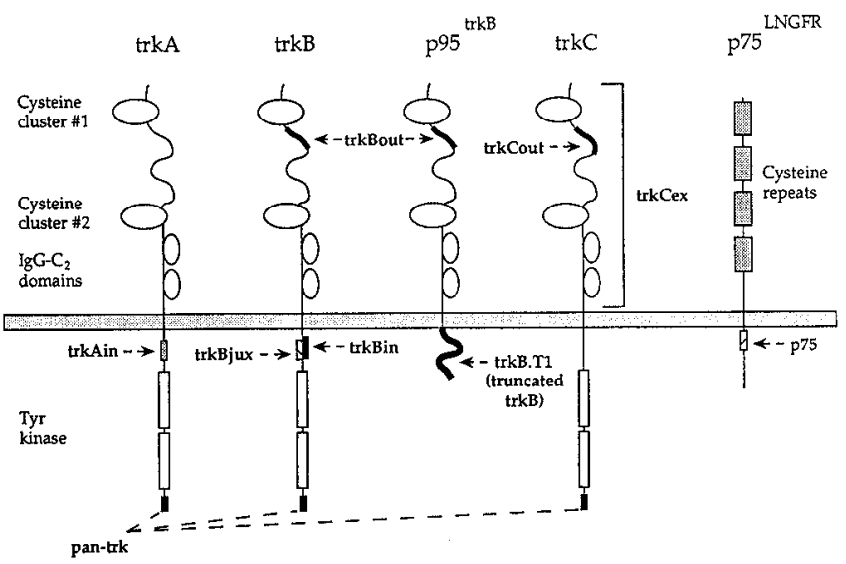

Figure 4. Schematic representation of anti-neurotrophin receptor antibodies used to identify BDNF and NT-3 cross-linked complexes. The antibodies used in this study are indicated in boldface. The arrows point to those protein sequences against which the specified antibodies were prepared.

against residues 258-276 of rat p75 (Shelton and Shooter, 1988; Allendoerfer et al., 1990).

The ability of NGF to compete with either BDNF or NT-3 for the cross-linking of the $100 \mathrm{kDa}$ band in retina suggested that this band might represent p75 (Rodriguez-Tébar et al., 1992). We noted, moreover, that the $100 \mathrm{kDa}$ bands labeled with BDNF and NT-3 in the retina and its target tissues comigrated with p 75 from PC 12 cells (Fig. $3 A$ ). The identity of the neurotrophinlabeled band in PC12 cells as p 75 was confirmed by immunoprecipitation (Fig. $3 B$, lanes 1,2 ). As shown in Figure $3 B$, lanes $5-7$, the $100 \mathrm{kDa}$ hand in retina was indeed immunoprecipitated by anti-p 75. Accordingly, we observed a comigrating $100 \mathrm{kDa}$ band in retina using iodinated NGF (Fig. 3A, lane 6). In contrast, wheras bands of similar size and intensity were labeled in the LGN and superior colliculus, neither were competed by unlabeled NGF or immunoprecipitated by anti-p75 (Fig. 3B, lanes $3,4)$. Thus, these observations indicate that while $\mathrm{p} 75$ is present in large amounts within the retina, within the LGN and superior colliculus it is undetectable. Other possible identities for the 100 $\mathrm{kDa}$ bands from LGN and superior colliculus include carboxyterminal truncated forms of trkB or trkC, alternately processed forms of trk-like molecules, or even novel species.

In order to distinguish among these alternatives and to identify the other cross-linked bands, immunoprecipitations were carried out on aliquots of cross-linked material from all visual tissues at P50, when the visual system is still immature but large amounts of material can be collected with relative ease, using the pan-trk, anti-truncated trkB, and anti-p 75 antibodies (Fig. $5 A, B)$. Iodinated BDNF and NT-3 were cross-linked to preparations of retina, LGN, superior colliculus, and cortex from P50 ferrets. The patterns of upper, middle, and lower bands observed at P50 were similar to those shown above for P10 and $P 3$, except that in the retinal target tissues the intensity of the lower band increased relative to that of the upper band (Fig. $5 \mathrm{~A}$ ). Again, the labeling of the $100 \mathrm{kDa}$ band in retina with NT3 , and, more faintly, with BDNF was completely competed by an excess of NGF, while the $100 \mathrm{kDa}$ cross-linked bands labeled with BDNF and NT-3 in the LGN, superior colliculus, and cortex were largely resistant to competition by NGF. As expected from the data shown above (Fig. $3 B$, lanes 6,7 ), the 100
$\mathrm{kDa}$ band in the retina (Fig. $5 \mathrm{~A}$, lanes 1,3 ) was immunoprecipitated only by anti-p75 (Fig. $5 B$, lane 4 ) while the $100 \mathrm{kDa}$ bands from the other tissues were immunoprecipitated only by the antibody specific for trkB.T I (Fig. $5 B$, lanes $8,13,18$ ). Thus, the $100 \mathrm{kDa}$ band cross-linked to BDNF in the superior colliculus, LGN, and cortex consists largely of truncated trkB. Antitruncated trkB was also able to immunoprecipitate a significant portion of the $100 \mathrm{kDa}$ NT-3-labcled bands in these tissues (Fig. $5 B$, lanes $11,15,21$ ) but not in retina (Fig. $5 B$, lane 5). This is probably due to some affinity of NT-3 for truncated trkB, consistent with our observation of partial reciprocal competition of BDNF and NT-3 for each other's labeling of the $100 \mathrm{kDa}$ band (see Fig. 2, lanes 11,13). The ability of NT-3 to bind to truncated trkB has been observed by others (Escandón et al., 1993).

The $145 \mathrm{kDa}$ and $155 \mathrm{kDa}$ complexes cross-linked with BDNF and NT-3, respectively, were immunoprecipitated by the pantrk antibody in all tissues that were analyzed (Fig. $5 B$ ). The size, specificity, and immunoprecipitation by the pan-trk antibody of these two bands suggest that they correspond to complexes containing the trkB molecule (for BDNF) and the trkC molecule (for NT-3), which have previously been shown to function as receptors for these neurotrophic factors in transfected cell lines (Klein et al., 1991b; Lamballe et al., 1991; Soppet et al., 1991; Squinto et al., 1991). It is unlikely that either band corresponds to a neurotrophin-trkA complex, given the inability of EDAC to mediate cross-linking of trkA to its ligand (Hosang and Shooter, 1985; Escandón and Chao, 1990; Meakin and Shooter, 1991). In order to extend the identification of the BDNF and NT-3 cross-linked complexes (demonstrated at P50 in Fig. $5 A, B$ ) to other ages before initiating a developmental study, immunoprecipitation analysis was performed on cross-linked complexes from retina, retinal targets, and visual cortex at E30 and P3 (Fig. 5C; data not shown). The $145 \mathrm{kDa}$ and $100 \mathrm{kDa}$ bands labeled by BDNF at these ages in LGN, superior colliculus, and visual cortex were again shown to correspond to complexes containing full-length and truncated trkB, respectively. The identity of the $155 \mathrm{kDa}$ NT-3-labeled band as a complex containing a member of the trk family (mostly likely trkC) was also confirmed at P3 (Fig. 5C). The $100 \mathrm{kDa}$ band labeled with either BDNF or NT-3 in retina was shown to contain p75 at E30 (data not shown) and at P3 (Fig. 3B) as well as at P50 (Fig. 5B), as shown previously. Thus, the identity of individual neurotrophin-labeled bands does not appear to change with development.

An additional band, slightly smaller than that corresponding to the putative full-length trkC complex, was also observed in immunoprecipitation of NT-3-labeled complexes by the pantrk antibody (Fig. 5B, lanes 6, 12,16,22). Given the specificity of the pan-trk antibody for the carboxy-terminus of trk family molecules, this particular species may correspond to some other member of the trk family (such as trkB), an alternately glycosylated form of trkC, or simply be an artifact of in vitro proteulysis or endoglycosidation. In addition, both BDNF and NT-3 specifically labeled unidentified bands with a size intermediate between the full-length trk molecules and trkB.T1 or p75 that could not be immunoprecipitated with the pan-trk antibody. These bands could represent novel species, posttranslational modifications of full-length trk molecules, or additional truncated forms. In particular, given the large number of alternately spliced variants of trkC (Garner and Large, 1992; ' Tsoulfas et al., 1993; Valenzuela et al., 1993), it is possible that the diffuse 

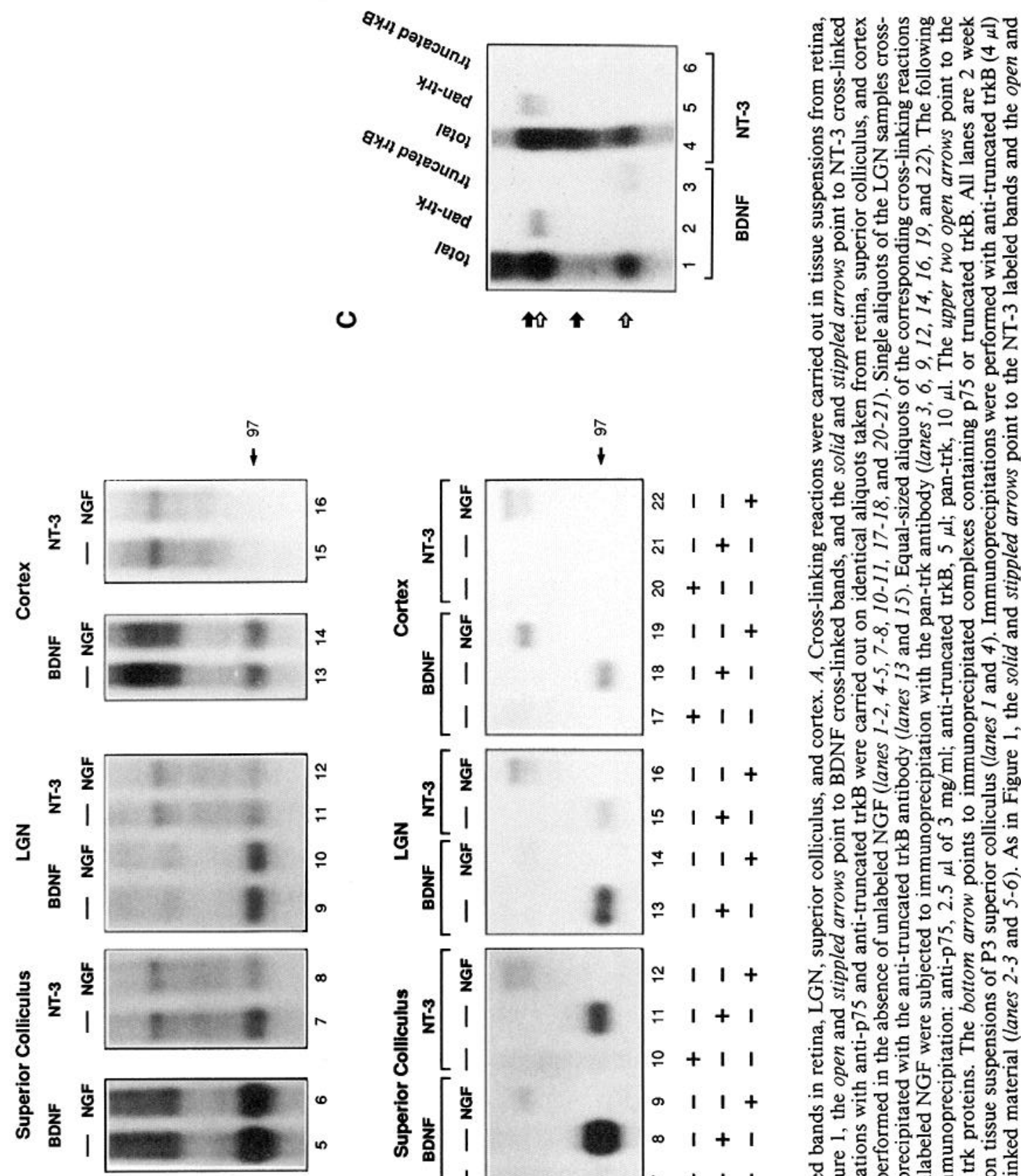

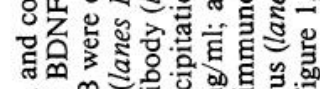
ㅇำ

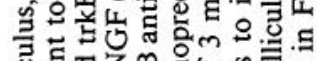

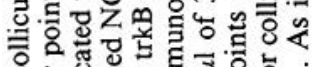
8

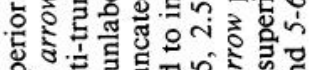

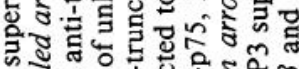

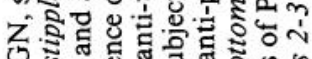

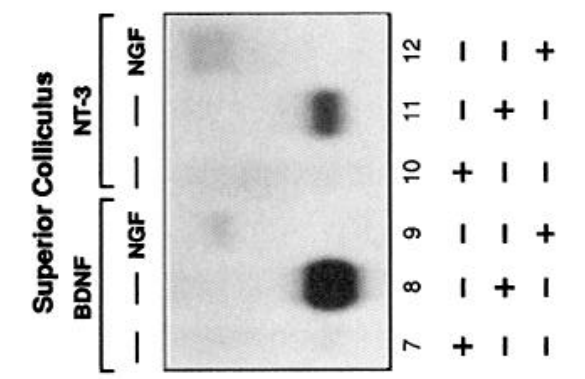

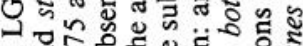

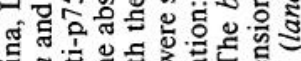

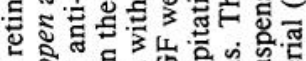

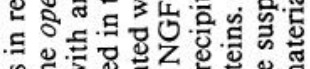

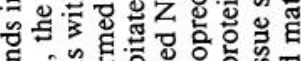

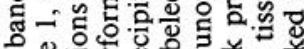

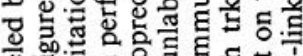

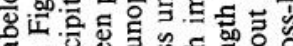
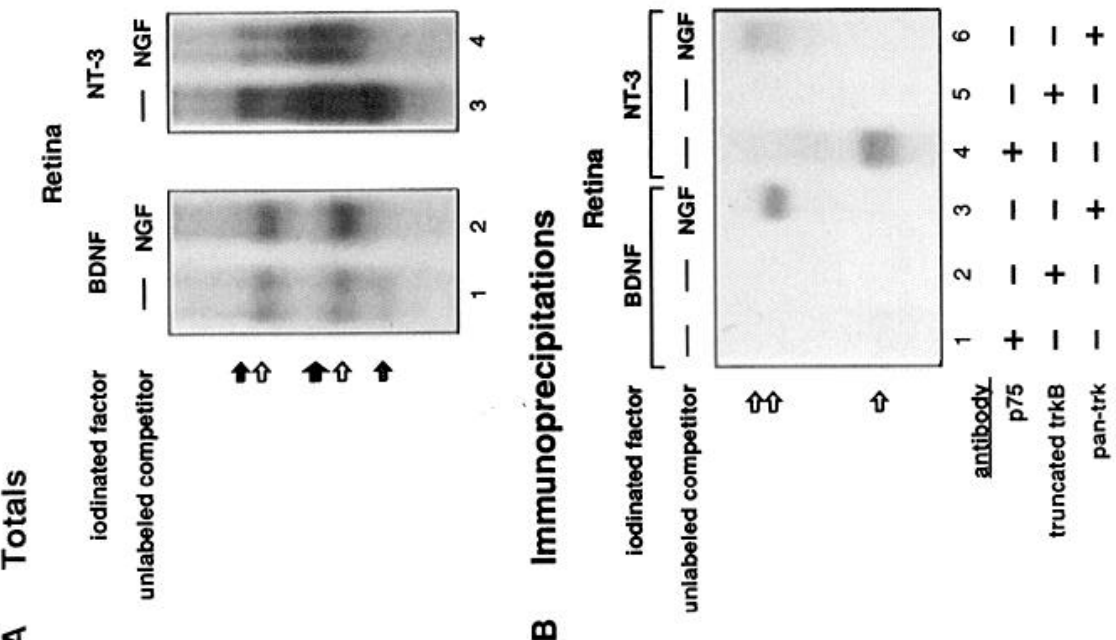

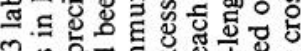

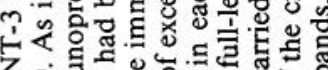
Z

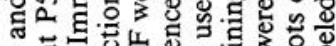

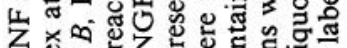

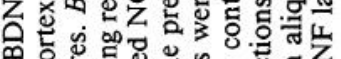
๓ फั สี

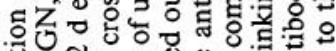

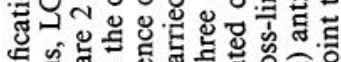

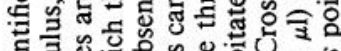

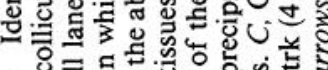
vi

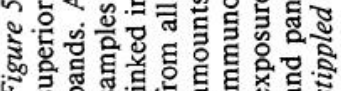




\section{A BDNF}

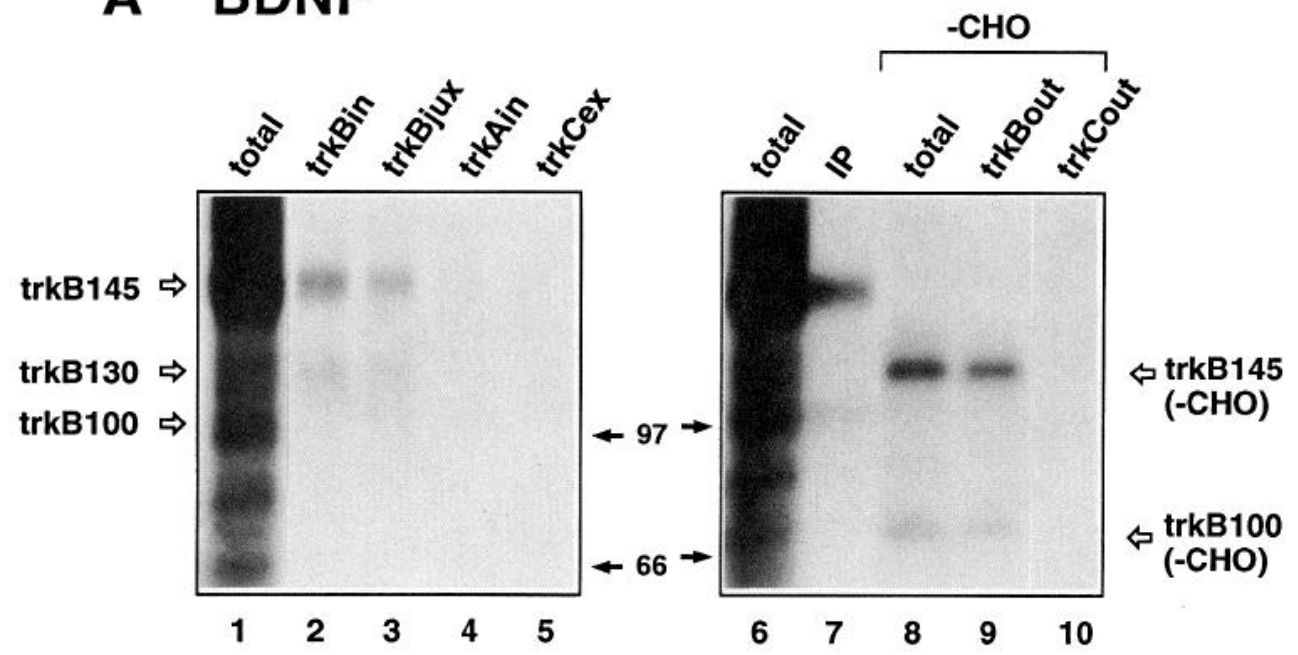

C

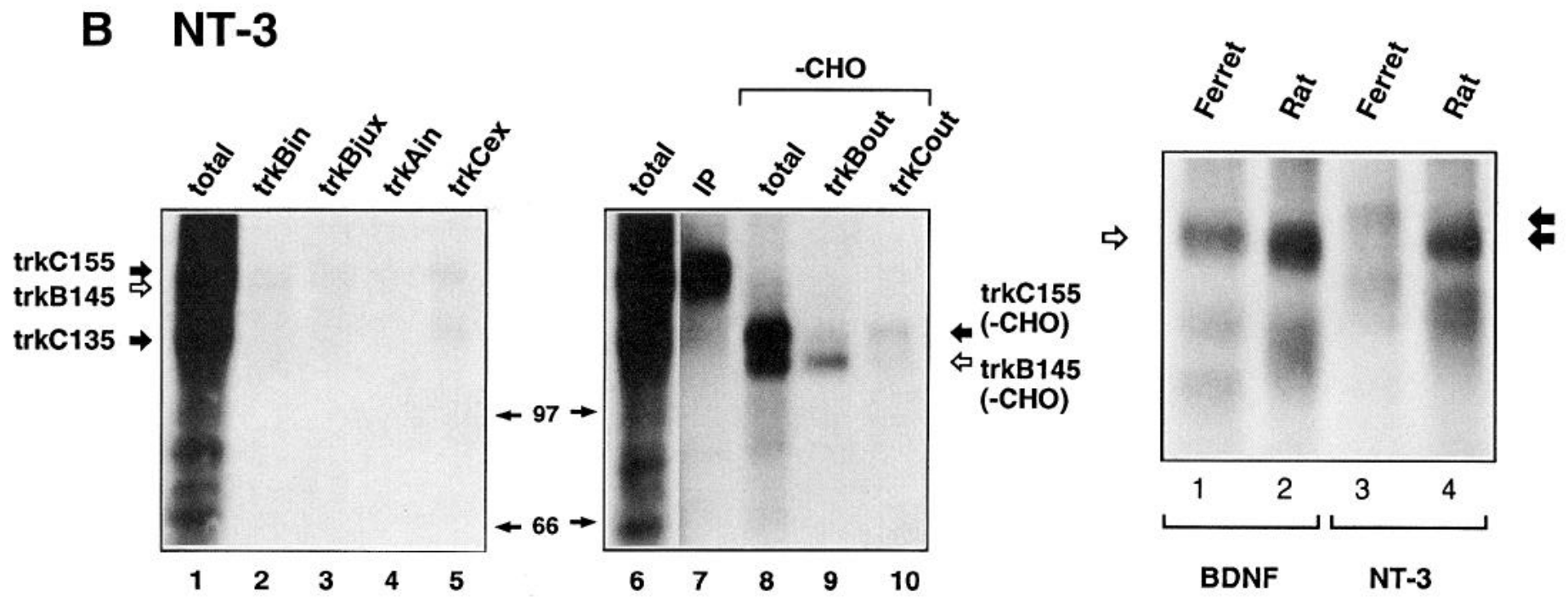

Figure 6. Identification of full-length trk molecules as trkB and trkC. $A$ and $B$, Cross-linking reactions were carried out on P29 ferret cortex. Iodinated BDNF $(A)$ and NT-3 $(B)$ were present at $3 \mathrm{~nm}$ in the presence of 150 nM unlabeled NGF. Equivalent aliquots of the solubilized crosslinked material were subjected to immunoprecipitation with anti-trkBin (lane 2), anti-trkBjux (lane 3), anti-trkAin (lane 4), and anti-trkCex (lane $5)$ as described in Materials and Methods. In each case, $12.5 \mu \mathrm{l}$ of antibody was used in a volume of $400 \mu \mathrm{l}$. Removal of sugar residues ( $-\mathrm{CHO}$ ) was achieved by immunoprecipitation with pan-trk with $(A$, lane 7$)$ or without anti-trkB.T1 $(B$, lane 7$)$, followed by incubation of the denatured immunoprecipitates with PNGase F as described in Materials and Methods (lanes 8-10). Equivalent aliquots were subjected to immunoprecipitation with anti-trkBout (lane 9) and anti-trkCout (lane 10). The open arrows point to full-length and putative alternately spliced forms of trkB; the solid arrows point to full-length and putative alternately spliced forms of the trkC. Immunoprecipitations were carried out on twice the amount of sample loaded in the total lanes, with or without deglycosylation. All lanes are $4 \mathrm{~d}$ exposures except for lanes $7-10$ in $B$. C, Comparison of cross-linked complexes in rat and ferret. Cross-linking reactions were carried out on P8 ferret cortex (lane 1) and LGN (lane 3) or on P1 rat cortex (lanes 2 and 4). All lanes are 1 week exposures.

intermediate NT-3-labeled band contains one or more of these species.

In order to provide conclusive identification of the full-length trk molecules, immunoprecipitations were carried out on BDNF and NT-3 cross-linked suspensions of P29 ferret cortex using antibodies specific for $\operatorname{trkA}, \operatorname{trkB}$, or $\operatorname{trkC}$, as shown in Figure 6. When BDNF was used in cross-linking, both the $145 \mathrm{kDa}$ and the $130 \mathrm{kDa}$ bands were immunoprecipitated by two antibodies directed against epitopes within the intracellular do- main of trkB, anti-trkBin and anti-trkBjux, but not by antitrkAin or anti-trkCex (Fig. $6 A$, lanes 1-5). In addition, complete deglycosylation of the $145 \mathrm{kDa}$ band allowed this species to be recognized by anti-trkBout, an antibody directed against an epitope within the extracellular domain of trkB, but not by trkCout (Fig. 6A, lanes 8-10). These observations prove that the 145 $\mathrm{kDa} \mathrm{BDNF}$-cross-linked complex contains full-length trkB and that the $130 \mathrm{kDa}$ BDNF-cross-linked complex contains an as yet unidentified form of trkB. In contrast, the $155 \mathrm{kDa}$ and 


\section{A Retina}

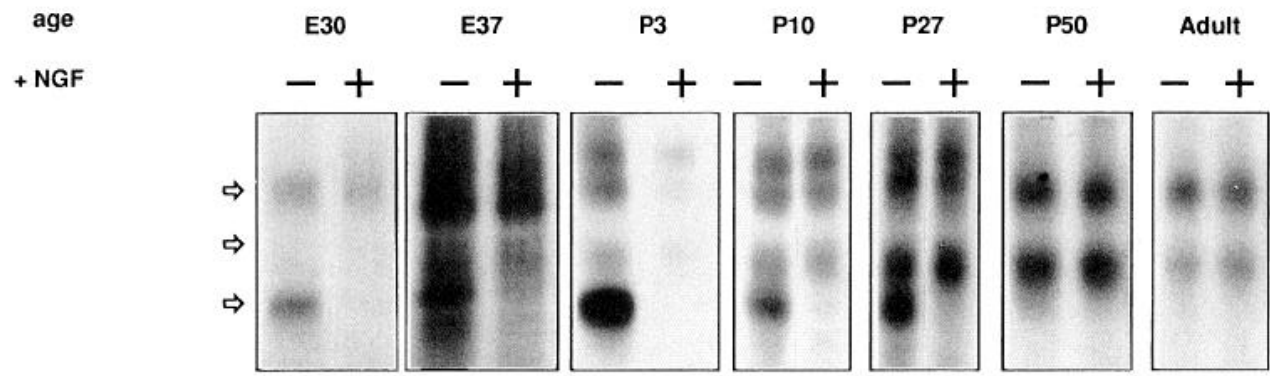

\section{B Superior Colliculus}

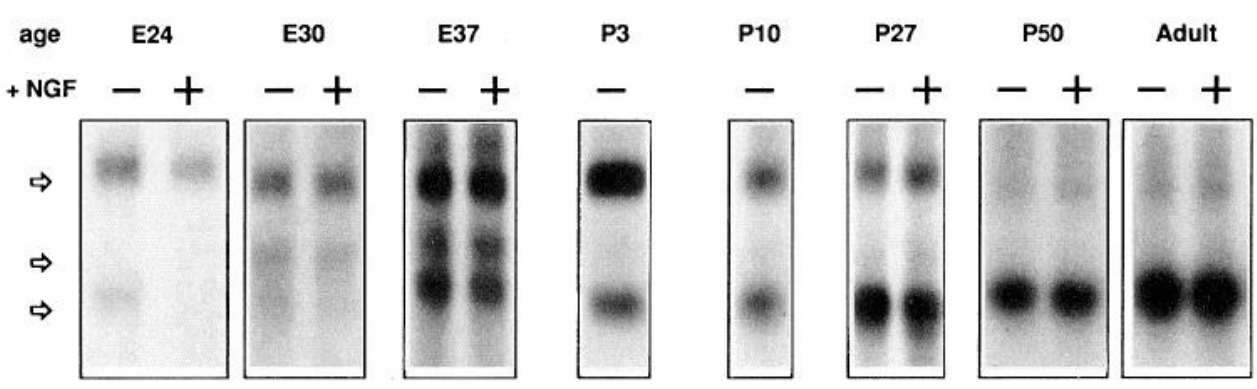

\section{LGN}

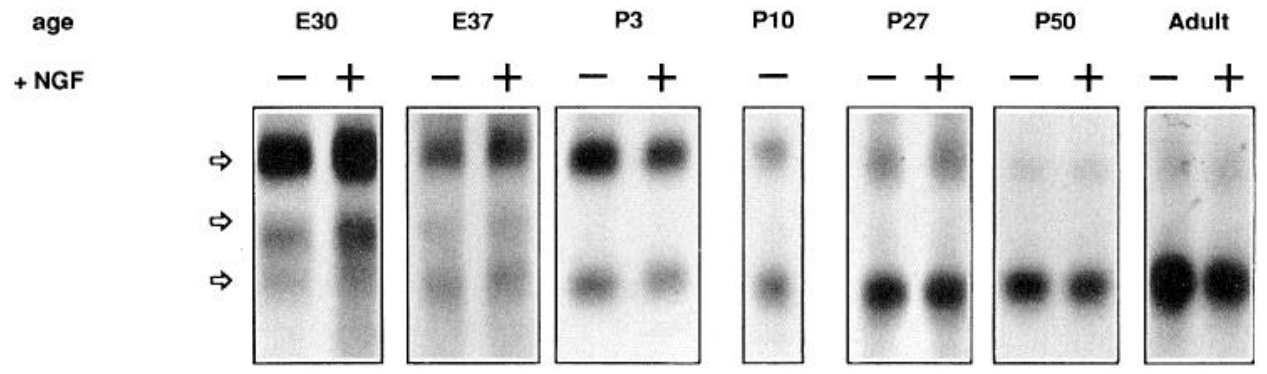

\section{Cortex}

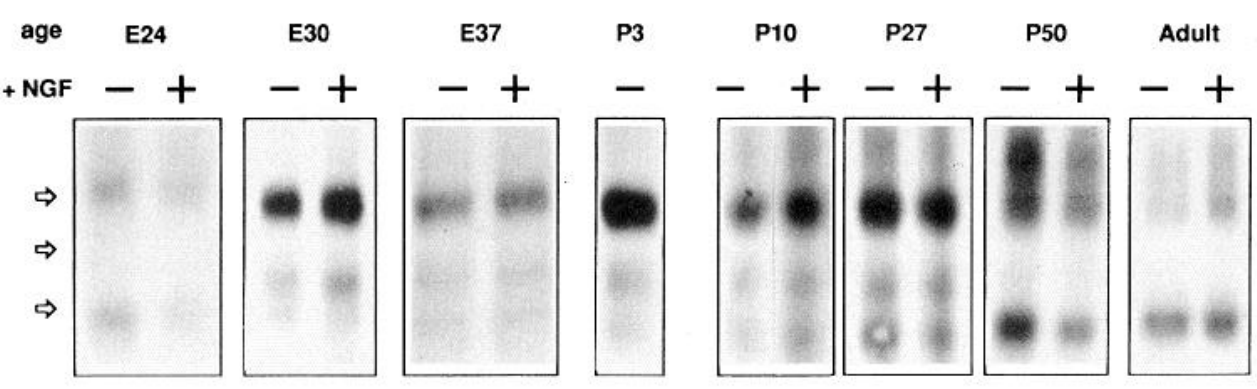

Figure 7. Developmental time series of BDNF cross-linking to retina, superior colliculus, LGN, and cortex. Cross-linking reactions were carried out using iodinated BDNF with $(+)$ and without ( - ) excess unlabeled NGF on tissue suspensions from retina $(A)$, superior colliculus $(B), \operatorname{LGN}(C)$, and cortex $(D)$ at various developmental ages. The data presented here for all tissues at any given age are derived from the same experiment. For all postnatal ages, two separate experiments were performed and yielded similar results. In each panel, the three arrows to the left point to the 145,130 , and $100 \mathrm{kDa}$ complexes containing BDNF.

diffuse $\sim 135 \mathrm{kDa}$ NT-3 cross-linked bands were preferentially immunoprecipitated by anti-trkCex, but only weakly recognized by antibodies to other members of the trk family (Fig. $6 B$, lanes $1-5)$. Deglycosylation of the pan-trk immunoprecipitate of NT-3 cross-linked material yielded two bands (Fig. $6 B$, lane 8), consistent with our observation that two distinct bands are often visible in pan-trk immunoprecipitates of this material (see Fig.
$5 B$, lanes $6,12,16,22)$. The larger band was immunoprecipitated by anti-trkCout (Fig. $6 B$, lane 10), showing that it corresponds to an NT-3-trkC complex. The smaller band was immunoprecipitated by anti-trkBout (lane 9) suggesting that the smaller band previously observed in pan-trk immunoprecipitates of NT-3 cross-linked material (see above) is an NT-3-trkB complex. 
A Ventricular Zone
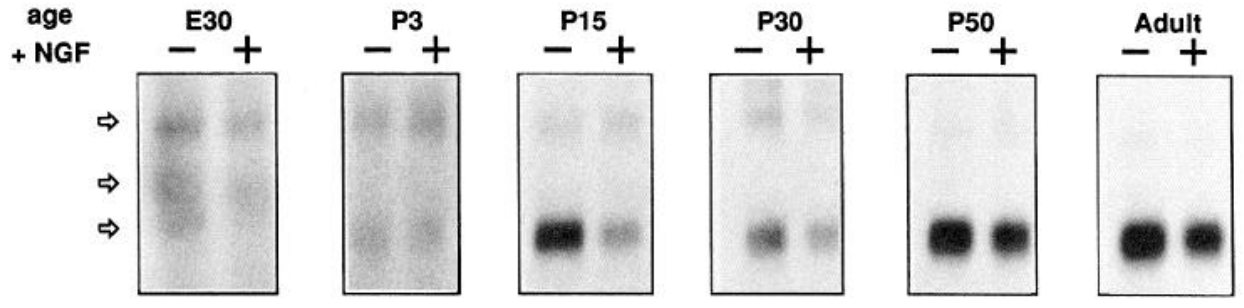

Figure 8. Developmental time series of BDNF cross-linking to subdivisions of cortex. Cross-linking reactions were carried out using iodinated BDNF with $(+)$ and without $(-)$ excess unlabeled NGF on tissue suspensions prepared from ventricular zone $(A)$, intermediate zone $(B)$, and cortical plate $(C)$ as described in Materials and Methods. Experiments at all ages were performed twice and yielded similar results. The data presented here for all tissues at any given age are derived from the same experiment. At E30, no distinction can yet be made between intermediate zone and cortical plate. Therefore, at that age, the upper half of the cortex was analyzed as a single unit. The three arrows on the left point to the 145,130 , and $100 \mathrm{kDa}$ complexes containing BDNF.

\section{B Intermediate Zone age
+ NGF}

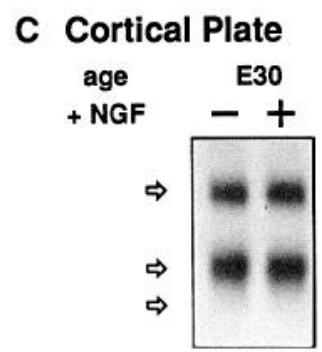

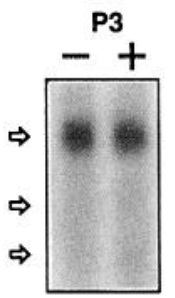

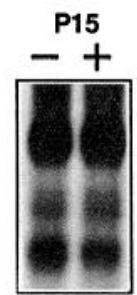

P3

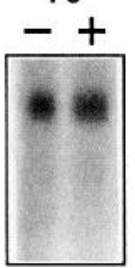

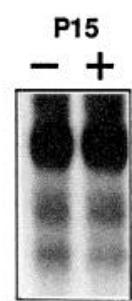
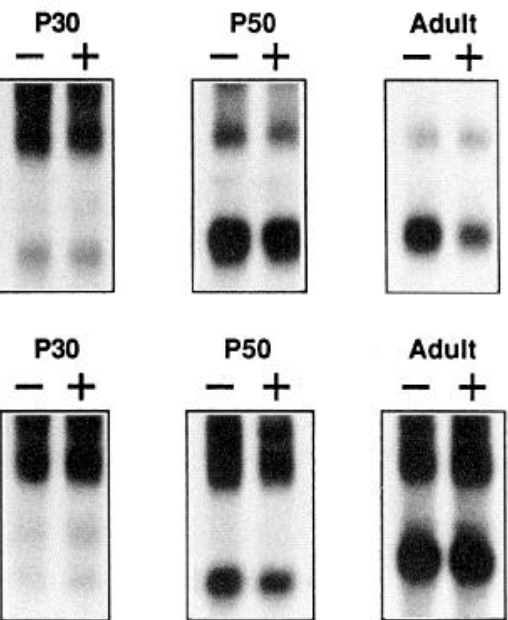

In view of the apparent discrepancy between the molecular sizes reported here for ferret trks and those reported by Escandón et al. (1993) for the rat trkB and trkC, a comparison was made of BDNF and NT-3 cross-linking between ferret and rat. As shown in Figure $6 C$, the ferret BDNF-trkB complex essentially comigrates with the rat BDNF-trkB complex, while the ferret NT-3-trkC complex is significantly larger than the rat NT-3trkC complex. The patterns of BDNF cross-linking are quite similar in the $\mathrm{P} 8$ ferret and $\mathrm{P} 1$ rat cortex preparations, as might be expected since these ages correspond to equivalent stages of cortical development in the two species.

These results demonstrate that BDNF binds specifically in all visual structures analyzed to full-length trkB, forming a complex of about $145 \mathrm{kDa}$. NT-3 binds primarily to full-length trkC $(155$ $\mathrm{kDa}$ ), although a minor amount of NT-3-trkB complex has also been observed. The retina contains abundant levels of $\mathrm{p} 75$, recognized by NGF, NT-3, or BDNF $(100 \mathrm{kDa})$. We have also observed the presence of the T1 truncated form of trkB in LGN, superior colliculus, and cortex that binds to and can be crosslinked with BDNF or with NT-3 $(100 \mathrm{kDa})$. It is notable that a small fraction of the $100 \mathrm{kDa}$ bands labeled by BDNF and, especially, by NT-3 in the LGN, superior colliculus, and cortex was in fact competed by addition of excess cold NGF, suggesting that some p75 may also be present at certain developmental stages. Finally, both the intermediate-size band labeled with BDNF (130 kDa), and the diffuse NT-3-labeled band ( 135 $\mathrm{kDa}$ ), which may contain multiple species, were not recognized by the pan-trk antibody, but could be immunoprecipitated by anti-trkB and anti-trkC antibodies, respectively. This suggests that these bands correspond either to alternately spliced forms of trkB and trkC (Tsoulfas et al., 1993; Valenzuela et al., 1993), or to receptors that have undergone proteolytic degradation at their carboxy termini.

\section{Developmental changes in BDNF receptors}

The data presented above demonstrate the presence of receptors for neurotrophic factors in the postnatal ferret visual system. In order to gain more insight into possible roles for these receptors in development, the cross-linking of BDNF was characterized at various times between E24 and adult (e.g., see Fig. 7). These ages were chosen to mark successive stages of retinal, geniculate, and cortical development, that is, cell division and differentiation, axon outgrowth, formation of mature patterns of connections, and developmentally regulated cell death.

Figure $7 A$ shows developmental changes in BDNF receptors in the retina between E30 and adulthood. The $145 \mathrm{kDa}$ band containing full-length trkB was present throughout development. The $130 \mathrm{kDa}$ band containing a variant of trkB increased in abundance relative to the full-length trkB-BDNF complex between $\mathrm{E} 30$ and P3; these complexes were thereafter present in similar amounts. However, the $100 \mathrm{kDa}$ band corresponding to p75 was present in significant amounts only through P27. In contrast to the other tissues (see below), in retina no truncated trkB could be detected by immunoprecipitation at any age analyzed.

Within superior colliculus, LGN, and cortex clear changes in cross-linked species were observed with increasing age. In the superior colliculus at E24 (Fig. 7B), two specific BDNF-labeled cross-linked products were observed: the $145 \mathrm{kDa}$ complex of BDNF with full-length trkB and a $100 \mathrm{kDa}$ BDNF-labeled band that was fully competed by excess NGF, indicating the presence of p75 but not truncated trkB. At E30 some 100 kDa BDNF- 
truncated trkB complex and some $130 \mathrm{kDa}$ complex were present but the vast majority of the BDNF-labeled product corresponds to complexes of BDNF with full-length trkB. During ensuing development the fraction of the label that is in this band declines continuously; in particular, between P3 and P27 the pattern of labeling shifts from being mostly BDNF cross-linked to full-length trkB to a predominance of complexes containing the truncated form of trkB. The latter pattern is maintained into adulthood. The amount of $130 \mathrm{kDa}$ band appeared to parallel the abundance of the $145 \mathrm{kDa}$ full-length trkB-BDNF complex; little if any was detected in P50 and adult. A nearly identical pattern of labeling was observed in the LGN (Fig. 7C). In cortex (Fig. $7 D$ ) a similar trend was observed as well, except that the shift in ratio of the trkB and truncated trkB-containing bands occurred somewhat later in development. Thus, between P27 and P50, the pattern of receptor cross-linking in cortex shifts from predominant labeling of full-length trkB to one in which slightly more labeling of truncated than of full-length trkB is observed. In addition, while p75 was present in cortex in significant amounts at E24, at later ages little p 75 could be detected.

While the cortex as a whole exhibits a particular temporal profile in the shift from full-length to truncated trkB, in fact the entire cerebral wall is composed of several embryonic zones in which developmental processes occur at different times; these zones include the ventricular zone, intermediate zone, and cortical plate. Cell division occurs in the ventricular zone, followed by the outward migration of neurons into the cortical plate. The ingrowth of thalamic axons into the cortex occurs in two stages: first, the axons arrive and branch among subplate neurons located within the intermediate zone just below the cortical plate; following a waiting period of several weeks the thalamic axons grow into their final targets, the layer 4 neurons. These inputs subsequently segregate into ocular dominance columns, accompanied by subplate neuron death (reviewed in Shatz et al., 1990). To address the possibility that the maturation of the ventricular zone, intermediate zone, and cortical plate, which occurs at different times, is reflected in each case by a coincident shift in ratio of trkB to truncated trkB, we increased the spatial resolution of our analysis by subdividing the cortex into ventricular zone, intermediatc zonc, and cortical plate prior to carrying out the cross-linking analysis (see Fig. 1). At E30 no boundary was apparent yet between the intermediate zone and cortical plate; therefore, the slices were only divided into ventricular zone and cortical plate at this age.

As shown in Figure $8 A$, in the ventricular zone only full-length trkB, the $130 \mathrm{kDa}$ band, and p 75 were found at E30. By P3, no p75 could be detected and full-length and truncated trkB were present in roughly equal amounts. By P15, truncated trkB was the predominant form of trkB in the ventricular zone and significant amounts of $\mathrm{p} 75$ were observed. In the intermediate zone, full-length trkB was the major receptor for BDNF at P3 and the truncated form did not emerge as the predominant species until P50 (see Fig. $8 B$ ). In contrast, in the cortical plate it is not until the adult that the majority of the BDNF crosslinked product corresponds to truncated trkB, and even at that time, full-length trkB constitutes nearly half of the total receptor (Fig. $8 C$ ). Thus, each of the subdivisions of cortex appears to undergo a shift from full-length to truncated trkB, but the timing and amount of the shift vary within each zone.

To evaluate more clearly the developmental regulation of these shifts in abundance of full-length trkB relative to the truncated form of trkB, the data shown in Figures 7 and 8 and

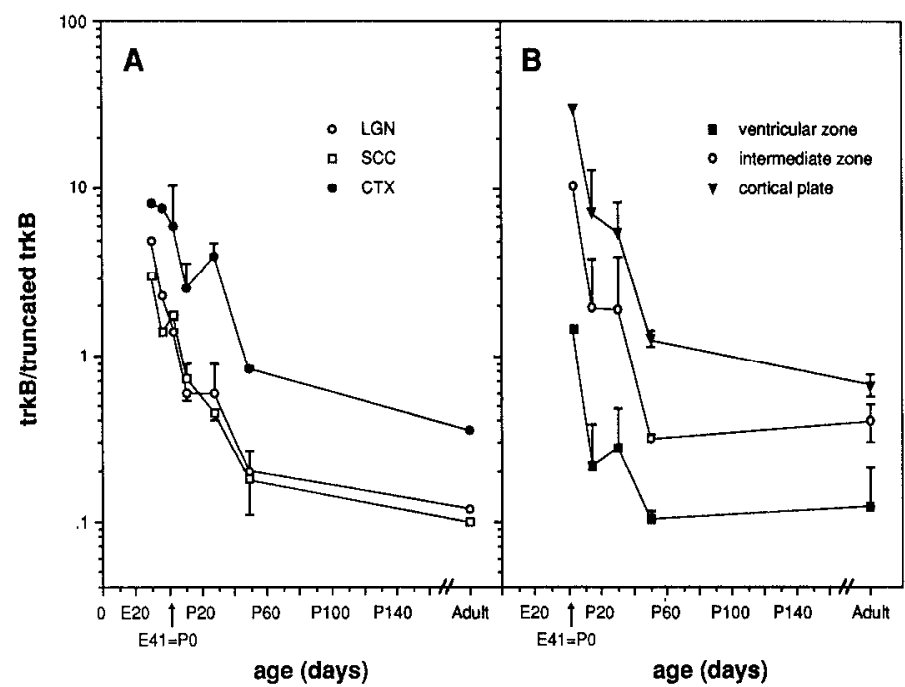

Figure 9. Quantitative analysis of developmental changes in the ratio of trkB to truncated trkB. Autoradiograms from the experiments shown in Figures 7 and 8 and additional experiments not shown were analyzed by densitometry as described in Materials and Methods. Lanes corresponding to experiments performed in the presence of $150 \mathrm{nM}$ NGF were analyzed in order to ensure that truncated trkB and not $\mathrm{p} 75$ was measured. $A$, Analysis of changes in the LGN, superior colliculus $(S C C)$, and cortex $(C T X)$. Data provided for the P3, P10, P27, and P50 time points are the averages of two separate experiments. $B$, Analysis of the cortex with respect to the three embryonic zones (ventricular zone, intermediate zone, cortical plate). Data from P15, P30, P50, and adult time points are the averages of two separate experiments. Ratios were plotted on a semi-log scale in order to give equal weight to changes that occur at ratios less than 1 and at ratios greater than 1. At E24 and E30, bands corresponding to BDNF-truncated trkB complexes were virtually undetectable. Thus, no ratio could be calculated for these early time points. Time is measured from the day of conception. In the ferret, birth occurs at $41 \mathrm{~d}$ postconception.

obtained in other experiments were quantified by densitometry. One limitation of the cross-linking technique is that absolute levels of cross-linked complexes cannot be compared between cxpcriments because of variability in the extent of cross-linking, the fact that cross-linking is a reflection of receptor concentration and affinity, and variability in the specific biological activity of the labeled neurotrophins. In addition, there is no suitable way of normalizing the signal from experiments carried out at different developmental ages. However, the ratio between a pair of labeled bands within a given cross-linking reaction is a measure that can be compared from experiment to experiment. Therefore, the ratios of full-length to truncated trkB identified by cross-linking to BDNF in the retinal target tissues and cortex are plotted against gestational age in Figure 9. The two retinal target tissues, LGN and superior colliculus, exhibit very similar developmental profiles, as seen in Figure $9 A$. In both tissues, the ratio is highest (between 3 and 5) at E30, the initial time point that could be quantified, falls to 1 between P3 and P10, and achieves a final value of $\sim 0.1$ by adulthood. In the cortex, the ratio of $\operatorname{trkB}$ to truncated trkB is $\sim 8$ at E30. The major decrease appears to occur later than in the LGN and superior colliculus, declining from $\sim 4$ at $\mathrm{P} 27$ to a value of $\sim 0.8$ at P50 and reaching a final value of $\sim 0.4$ in the adult. Figure $9 B$ shows the temporal shift in ratios of the three subdivisions of cortex. In the ventricular zone, only full-length trkB could be detected at $\mathrm{E} 30$, but by $\mathrm{P} 3$ the ratio of full-length to truncated trkB was 
A LGN

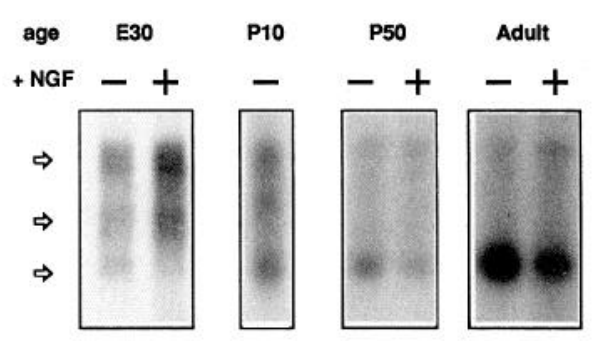

C Cortex

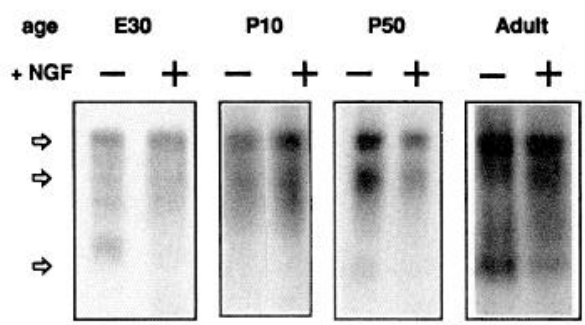

B Superior Colliculus

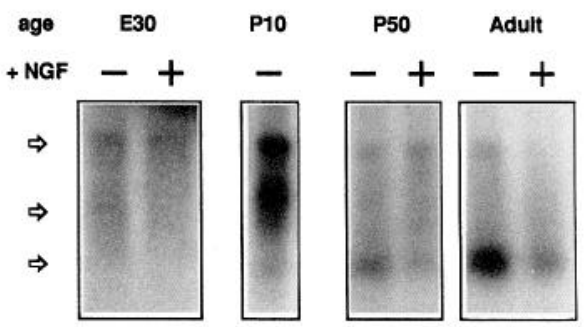

D Retina

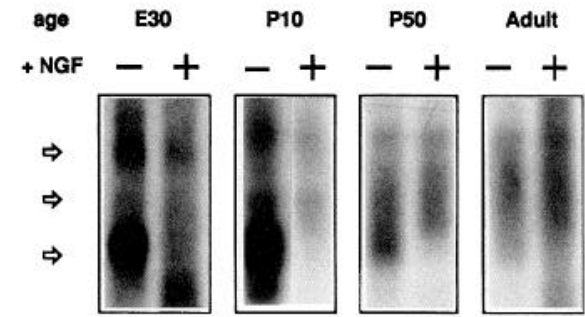

$\sim 1.5$. By P15, the ratio had declined to $\sim 0.2$, similar to the adult value of $\sim 0.12$. In the intermediate zone, the ratio was $>10$ at P3, declined from $\sim 2$ to $\sim 0.3$ between P30 and P50, and remained at this level into adulthood. In the cortical plate, the ratio was $\sim 30$ at $\mathrm{P} 3$, and remained above 5 through P30. By P50, the ratio had declined to $\sim 1.3$, and achieved a final adult value of $\sim 0.7$. This analysis demonstrates a systematic shift from full-length to truncated trkB in each of these structures, with the shift occurring at significantly later ages in the intermediate zone and cortical plate of the cerebral cortex than elsewhere. The change in the ratio of cross-linked full-length to truncated trkB that we have observed during visual system development may reflect a change in receptor concentration or in affinity, either of which would be significant in terms of biological responsiveness to neurotrophins.

\section{Developmental pattern of $N T-3$ receptors}

In a final set of experiments, we examined the cross-linking of iodinated NT-3 at different times in development. As shown in Figure 10 , the $155 \mathrm{kDa}$ band corresponding to the NT-3-trkC complex was present at all ages in LGN, superior colliculus, and cortex (Fig. 10A-C). Moreover, when the cortex was subdivided into ventricular zone, intermediate zone, and cortical plate, NT-3 was cross-linked to full-length trkC at all ages in all three regions, including the ventricular zone at E30 (data not shown). The $\sim 135 \mathrm{kDa}$ band(s) containing putative trkC isoforms was also generally present throughout development. The labeling of the $100 \mathrm{kDa}$ bands also increased over time relative to labeling of trkC, especially in the LGN and superior colliculus, but this increase was not as marked as that observed with iodinated BDNF. The intense $100 \mathrm{kDa}$ band at the P50 and adult time points in LGN and superior colliculus reflects binding of NT-3 to the large amounts of truncated trkB present at those ages and, in addition, to significant amounts of p75, as suggested by the ability of excess unlabeled NGF to compete for the labeling of a fraction of this $100 \mathrm{kDa}$ band. Indeed, at E30 in the cortex the $100 \mathrm{kDa}$ NT-3 labeled band was fully competed by inclusion of excess NGF, indicating that this band contained exclusively p75 at this time. The identity of this band at E30 was confirmed by immunoprecipitation with anti-p75 (data not shown).

In retina (Fig. 10D), as in the other tissues, a signal corresponding to the $155 \mathrm{kDa}$ complex of NT-3 with trkC was observed throughout development. However, nearly all of the NT-3 labeling at ages E30 through P27 was of a $\sim 100 \mathrm{kDa}$ band identified as p75 by NGF competition and immunoprecipitation (Figs. 3, 5; data not shown). At later times (P50 and adult), it appeared that the amount of NT-3-p75 complex was significantly reduced while the unidentified diffuse band increased in intensity.

The results presented here demonstrate that receptors for BDNF and NT-3 are present in the visual system throughout development. These receptors have been identified as members of the trk family of receptor tyrosine kinases (trkB and trkC) and the low-affinity NGF receptor (p75). Moreover, the relative proportions of $\mathrm{p} 75$ and the full-length and truncated forms of trkB are developmentally regulated in retinal target tissues and visual cortex.

\section{Discussion}

$B D N F$ and NT-3 bind to trk tyrosine kinase receptors in the visual system

We have provided evidence that members of the trk family are present within the developing mammalian visual system as functional receptors that avidly and selectively bind specific neurotrophic factors. By using cross-linking to iodinated neurotrophins, trk proteins have been identified as receptors for BDNF and NT-3. These receptors correspond to full-length trkB and trkC, to trkB.T1, and most likely, to additional alternately spliced forms of trkB and trkC. The expression or activity of full-length trkB and truncated trkB are differentially regulated in a manner that correlates temporally with the local pace of development.

The demonstration that trkB and trkC are receptors for neu- 
rotrophic factors has come about primarily through analysis of cell lines transfected with DNA encoding the various trk molecules (Klein et al., 1991 b; Lamballe et al., 1991; Soppet et al., 1991; Squinto et al., 1991). However, the evidence that these receptor proteins are present and functional within the brain has been largely indirect, relying on the identification in rodent brain of transcripts predicted to encode trkC and full-length and truncated forms of trkB (Klein et al., 1989, 1990a,b; Lamballe et al., 1991; Middlemas et al., 1991), and on the identification of full-length and truncated forms of trkB protein by immunoblot in extracts of whole adult mouse brain (Klein et al., 1990a).

We have used cross-linking of iodinated BDNF and NT-3 to dissociated tissue preparations to determine that each factor binds to a discrete set of proteins within visual system structures. BDNF cross-linking generated the $145 \mathrm{kDa}$ complex, but not the $155 \mathrm{kDa}$ complex, and similarly NT-3 cross-linking mainly generated the $155 \mathrm{kDa}$ complex. This observation and the partial selectivity of competition with cold neurotrophins indicate that BDNF and NT-3 bind primarily to different trk molecules. The lack of competition at either receptor by excess unlabeled NGF suggests that neither corresponds to the trkA proto-oncogene. TrkC has been shown in cell lines to be a highly specific receptor for NT-3, while trkB shows a moderate preference for BDNF over NT-3 (Klein et al., 1991 b; Lamballe et al., 1991; Soppet et al., 1991; Squinto et al., 1991). Finally, by direct immunoprecipitation with trkB-and trkC-specific antibodies, we have confirmed that BDNF binds to trkB and NT-3 binds to trkC in this system.

While EDAC has been shown to mediate cross-linking of NGF to 75 but not to trkA [in contrast to certain other reagents, including hydroxysuccinimidyl-4-azidobenzoate (HSAB)] (Escandón and Chao, 1990; Meakin and Shooter, 1991), this reagent is able to cross-link BDNF and NT-3 to trk molecules (this study and Escandón et al., 1993). Moreover, since no differences between EDAC- and HSAB-mediated cross-linking have been noted in mouse cortex with either BDNF or NT-3 (E. Escandón and $\mathrm{K}$. Nikolics, unpublished observations), it is unlikely that the choice of EDAC as cross-linking reagent has resulted in any loss of information.

\section{P75 is a prominent neurotrophin receptor during retinal development}

Our data indicate that $\mathrm{p} 75$ is present in the retina and is able to bind to BDNF and NT-3 as well as NGF. This observation agrees with previous results showing that all three ligands are able to bind with similar affinity to p75 in peripheral neurons and PC12 cells (Rodriguez-Tébar et al., 1990, 1992). We have also observed the presence of $\mathrm{p} 75$ to a much lesser extent within retinal targets. These results are in agreement with previous immunohistochemical observations of $\mathrm{p} 75$ in retina and retinal target tissues (Schatteman et al., 1988; Yan and Johnson, 1988; Henderson, 1991; Rickman et al., 1991). However, it was difficult to prove the presence of $\mathrm{p} 75$ in the target tissues by crosslinking because of the comigration of the p75-neurotrophin complex with the truncatcd trkB-neurotrophin complex, and the extremely low efficiency of immunoprecipitation by the antip75 antibody (see Figs. 3, 5). Henderson (1991) reported that p75 immunostaining in ferret retina and retinal targets was absent by $\mathrm{P} 2$, but we have observed neurotrophin cross-linking to p75 in the retina as late as P50. P75 is known to be present in connective tissue (Wheeler and Bothwell, 1992), so it is possible

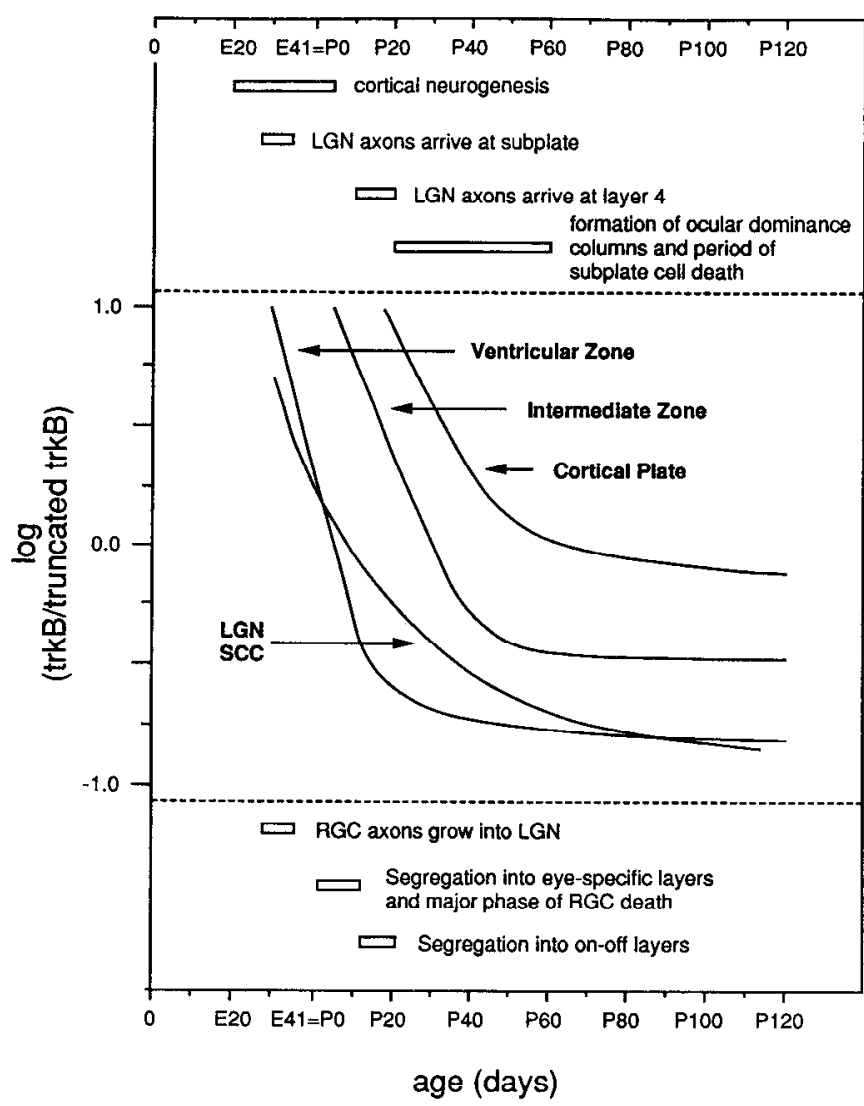

Figure 11. Changes in ratio of trkB to truncated trkB coincide with the maturation of connections in the visual system. Curves were drawn to fit the data points plotted in Figure $9 A$ for LGN and $9 B$ for the three subdivisions of cortex and are compared with time courses of specific events in the maturation of the retinogeniculate pathway and the cortex. In the retinogeniculate pathway, invasion of the LGN by ganglion cell axons occurs between E28 and E36 (Cucchiaro and Guillery, 1984) and the major phase of ganglion cell death occurs between birth and P6 (Henderson et al., 1988). Axonal segregation to form LGN layers takes place between P1 and P21 (Linden et al., 1981; Hahm et al., 1991). The timing of some events in the ferret cortical development was extrapolated from information on the development of the cat visual system, which occurs with a similar time course, combined with the following experimentally determined information: cortical neurogenesis in the ferret occurs between E20 and P4 (Jackson et al., 1989). Thalamic axons have been reported to first arrive at the cortex by E27 (Johnson and Casagrande, 1993) and to arrive in cortical layer 4 beginning at $\mathrm{P} 10$ (K. Herrmann and C. J. Shatz, unpublished observations). Ocular dominance columns in the ferret have formed by P60 (M. P. Stryker, personal communication).

that our cross-linking result is due in part to p75 present in retinal basement membranes.

In whole cortex, we detected p75 from E24 through E37, and in the cortical subdissection experiments, p75 was localized primarily to the ventricular zone. This finding is consistent with p75 observed in the ventricular zone by immunohistochemistry (K. L. Allendoerfer and C. J. Shatz, unpublished observations). On the other hand, virtually no $\mathrm{p} 75$ could be detected by crosslinking in the intermediate zone, despite the observed immunostaining for p75 in subplate neurons during development (Allendoerfer et al., 1990; Koh and Higgins, 1991; Wayne et al., 1991; Kordower and Mufson, 1992; Meinecke and Rakic, 1993). Complete agreement between cross-linking and immunostaining might not be expected, given the very different nature of the two techniques. Just as for retinal fibers, subplate neurons rep- 
resent a very small percentage of the total tissue volume, and any p75 signal derived from them could be undetectable in cross-linking experiments. We also observed p75 expression early (E24) in the colliculus, before any truncated trkB could be observed. Thus, in both the midbrain and cortex, $\mathrm{p} 75$ was most abundant well before the first detection of truncated trkB.

\section{Regulation of BDNF receptors correlates with visual system development}

We have made three primary observations with regard to the localization and expression of receptors for BDNF during development. First, they have been found throughout the visual system. Second, the ratio of truncated trkB to full-length trkB increases markedly (over an $\sim 100$-fold range) over time. Last, the periods of sharpest decline in ratio coincide with the periods in which neurogenesis is complete and mature patterns of connections form, within both retinal target tissues and the latermaturing visual cortex. In addition, we identified $\mathrm{p} 75$ very early in development of the cortex and tectum, when both of these structures consist primarily of dividing stem cells in a ventricular zone, and we also observed full-length trkB and trkC in the ventricular zone throughout the period of cortical neurogenesis.

Figure 11 presents a summary of some of the critical time points in the development of the ferret visual system. During the development of the retinogeniculate pathway, axon growth into the LGN (E28-E36) (Cucchiaro and Guillery, 1984) is followed by a major phase of ganglion cell death that is coincident with the period of segregation into eye-specific layers (P0-P10) (Linden et al., 1981; Henderson et al., 1988). It has been shown that there is also a considerable loss of LGN neurons, which takes place prior to segregation (Williams and Rakic, 1988). These LGN neurons project to the visual cortex, and are also the target of back-projections from the cortex. Within the LGN, we have observed trophic factor receptors throughout this developmental period, but our cross-linking analysis does not allow us to say whether these receptors are localized to the axon terminals of projections from the retina, from the cortex, or to the LGN neurons themselves. The dependence of retinal ganglion cell survival on diffusible substances released by target tissues has been suggested in studies of ganglion cell survival in culture (Armson and Bennett, 1983; Johnson et al., 1986). Thus, receptors on retinal axon terminals could mediate the response of ganglion cells to target-derived neurotrophic signals. On the other hand, ligand-receptor interactions may also take place in other parts of the system; for example, LGN neuron soma size and survival are known to be dependent on diffusible factors derived from the cortex (Cumningham et al., 1987; Domenici et al., 1991b).

Similar types of interactions could be involved in the regulation of cortical development. From E20 to P4, stem cells in the ventricular zone divide (Jackson et al., 1989) and give rise to neurons of multiple phenotypes that migrate out and form the layers of the cortical plate (McConnell, 1991). The presence of full-length neurotrophin receptors and p75 in the ventricular zone at this early time raises the possibility that neurotrophins might play a role in cell division or cell fate determination. During ensuing cortical development, thalamic axons segregate into ocular dominance columns by P60 (M. P. Stryker, personal communication). In the cat, ocular dominance column formation is accompanied by the death of $80-90 \%$ of the subplate neurons (Chun and Shatz, 1989). Neuron death also takes place in the neonatal cortical plate (Finlay and Slattery, 1983). Sur- vival of subplate and cortical plate neurons could be mediated by interactions between neurotrophins and the neurotrophin receptors whose existence has been demonstrated in this study. In addition to their role in cell survival, neurotrophic factors may also modulate the pattern of axonal connections during such processes as the formation of eye-specific layers in the LGN and ocular dominance columns in visual cortex (Domenici et al., 1991a).

In this context, we have observed that the decrease in the ratio of full-length to truncated trkB in the retinal targets, subplate, and cortical plate coincides with periods of cell death during which axonal projections achieve their mature morphologies and target specificities. In the ventricular zone, this decrease in ratio coincides with the end of the period of neurogenesis (Fig. 11). To interpret the significance of these correlations requires an understanding of the possible functions of truncated trkB. A number of biochemical activities have been suggested for those truncated forms of trkB that lack the cytoplasmic tyrosine kinase domain. These possibilities include (1) the idea that truncated trkB could reduce responsiveness to neurotrophins by either acting as a dominant negative effector of full-length trkB function or serving as a nonfunctional sink for ligand, (2) a role for truncated trkB in the presentation of neurotrophin to cells bearing the full-length receptor (Klcin ct al., 1990a), and (3) that truncated trkB might possess adhesive properties by virtue of its limited homology to known cell adhesion molecules (Schneider and Schweiger, 1991). In the ensuing discussion, we will focus on those models in which truncated trkB reduces neurotrophin responsiveness.

Kashles et al. (1991) have suggested from studies of the epidermal growth factor receptor that autophosphorylation-mediated activation of tyrosine kinase receptors occurs through a transphosphorylation mechanism that is dependent on ligandinduced receptor dimerization. Thus, truncated trkB might be able to reduce the responsiveness of intact trkB to BDNF through the formation of nonfunctional heterodimers, as has now been shown for other receptor tyrosine kinases (Amaya et al., 1991; Kashles et al., 1991; Jing et al., 1992; Ueno et al., 1992). Alternately, the truncated receptor may serve as a sink for ligand. In these scenarios, an increase in the proportion of the truncated form of trkB could reduce ganglion cell responsiveness to targetderived neurotrophic factor, leading to competition for limiting amounts of factor. Of course, this competition for neurotrophins could affect processes in addition to selective cell death, such as synapse formation and maintenance (Lohof et al., 1993). In this way, neurotrophic factors may play a role in the remodeling component of axonal segregation. In this regard, it is notable that Knüsel et al. (1994) have demonstrated a progressive reduction in autophosphorylation of full-length trk protein in response to BDNF as development proceeds. As in this study, the timing of the reduced responsiveness in several different brain areas generally correlated with the timing of maturation of the particular structure.

It might be argued that the simplest way to make neurotrophin availability limiting for cell survival or synapse maintenance is to reduce the amount of the neurotrophin synthesized by the target. However, this line of reasoning does not take into account that a given target structure may provide trophic support to multiple inputs that undergo selective cell death and axon remodeling at different times. For example, the LGN receives inputs from both the retina and cortex. Selective cell death of retinal ganglion cells, which may be based on competition for 
limiting amounts of neurotrophin, occurs early in development, while cell death in the subplate and cortical plate takes place much later (see Fig. 11). Thus, a general reduction in neurotrophin availability at a time appropriate for one set of inputs would be inappropriate for the other. On the other hand, a selective reduction in the responsiveness of the afferent neurons to neurotrophin, achieved either through the formation of trkB-truncated trkB heterodimers or through spatially restricted expression of truncated trkB that acts locally to bind up available neurotrophin, would allow competition to take place in each system at the appropriate time.

Models of the in vivo roles of full-length and truncated trkB in visual system development depend on the cellular localization of these receptors. The trkB-truncated trkB heterodimer model assumes that the two receptor types are expressed within the same cell. Although published reports show a nonoverlapping distribution of transcripts for the two forms in the adult (Klein et al., 1990a), we have shown the localization of trkB and truncated trkB within the same tissues during development. More precise localization of receptors and identification of neurotrophic factors within the system will be necessary to distinguish among the many possibilities discussed above. For example, preliminary immunohistochemical experiments to determine the cellular pattern of expression of these receptors have shown that specific sets of neurons within the developing visual system are immunoreactive for trkB (Cabelli et al., 1993). Whatever the specific functions of these forms of $\operatorname{trkB}$, our observations indicate a definite role for neurotrophic factors and their receptors in visual system development. Interplay between full-length and truncated forms of trkB is unlikely to be restricted to the visual system; we found that the inferior colliculus gave nearly identical cross-linking results as the superior colliculus throughout development (results not shown). Thus, these observations may be generally applicable to mechanisms controlling the maturation of cell types and connections throughout the CNS.

\section{References}

Allendoerfer KL, Shatz CJ (1994) The subplate, a transient neocortical structure: its role in the development of connections between thalamus and cortex. Annu Rev Neurosci 17:185-218.

Allendoerfer KL, Shelton DL, Shooter EM, Shatz CJ (1990) Nerve growth factor receptor immunoreactivity is transiently associated with the subplate neurons of the mammalian cerebral cortex. Proc Natl Acad Sci USA 87:187-190.

Amaya E, Musci TI, Kirschner MW (1991) Expression of a dominant negative mutant of the FGF receptor disrupts mesoderm formation in Xenopus embryos. Cell 66:257-270.

Anderson DJ, Axel R (1986) A bipotential neuroendocrine precursor whose choice of cell fate is determined by NGF and glucocorticoids. Cell 47:1079-1090.

Antonini A, Stryker MP (1993) Development of individual geniculocortical arbors in cat striate cortex and effects of binocular impulse blockade. J Neurosci, 13:3549-3573.

Armson PF, Bennett MR (1983) Neonatal retinal ganglion cell cultures of high purity: effect of superior colliculus on their survival. Neurosci Lett 38:181-186.

Barde Y-A, Edgar D, Thoenen H (1982) Purification of a new neurotrophic factor from mammalian brain. EMBO J 1:549-553.

Barres BA, Silverstein BE, Corey DP, Chun LLY (1988) Immunological, morphological, and electrophysiological variation among retinal ganglion cells purified by panning. Neuron 1:791-803.

Berkemeier LR, Winslow JW, Kaplan DR, Nikolics K, Goeddel DV, Rosenthal A (1991) Neurotrophin-5: a novel neurotrophic factor that activates trk and trkB. Neuron 7:857-866.

Cabcll RJ, Allendocrfer KL, Radcke MJ, Feinstein SC, Shatz CJ (1993) Developmental pattern of trkB immunoreactivity in the mammalian cerebral cortex. Soc Neurosci Abstr 19:1296.
Carmignoto G, Maffei L, Candeo P, Canella R, Comelli C (1989) Effect of NGF on the survival of rat retinal ganglion cells following optic nerve section. J Neurosci 9:1263-1272.

Castrén E, Zafra F, Thoenen H, Lindholm D (1992) Light regulates expression of brain-derived neurotrophic factor mRNA in rat visual cortex. Proc Natl Acad Sci USA 89:9444-9448.

Cattaneo E, McKay R (1990) Proliferation and differentiation of neuronal stem cells regulated by nerve growth factor. Nature 347:762765

Chao MV, Bothwell MA, Ross AH, Koprowski H, Lanahan AA, Buck CR, Sehgal A (1986) Gene transfer and molecular cloning of the human NGF receptor. Science 232:518-521.

Chun JJM, Shatz CJ (1989) Interstitial cells of the adult neocortical white matter are the remnant of the early generated subplate neuron population. J Comp Neurol 282:555-569.

Cohen-Cory S, Dreyfus CF, Black IB (1991) NGF and excitatory neurotransmitters regulate survival and morphogenesis of cultured cerebellar Purkinje cells. J Neurosci 11:462-471.

Cowan WM, Fawcett JW, O'Leary DDM, Stanfield BB (1984) Regressive events in neurogenesis. Science 225:1258-1265.

Cucchiaro J, Guillery RW (1984) The development of the retinogeniculate pathways in normal and albino ferrets. Proc R Soc Lond [Biol] 223:141-164.

Cunningham TJ, Haun F, Chantler PD (1987) Diffusible proteins prolong survival of dorsal lateral geniculate neurons following occipital cortex lesions in newborn rats. Dev Brain Res 37:133-141.

Diamond J, Holmes M, Coughlin M (1992) Endogenous NGF and nerve impulses regulate the collateral sprouting of sensory axons in the skin of the adult rat. J Neurosci 12:1454-1466.

Domenici L, Berardi N, Carmignoto G, Vantini G, Maffei L (1991a) Nerve growth factor prevents the amblyopic effects of monocular deprivation. Proc Natl Acad Sci USA 88:8811-8815.

Domenici L, Celerino A, Maffei L (1991b) NGF prevents the shrinkage of neurons in lateral geniculate nucleus (LGN) of monocularly deprived rats. Soc Neurosci Abstr 17:1136.

Dreyfus CF (1989) Effects of nerve growth factor on cholinergic brain neurons. Trends Pharmacol Sci 10:145-149.

Ernfors P, Ibanez CF, Ebendal T, Olson L, Persson H (1990) Molecular cloning and neurotrophic activities of a protein with structural similarities to nerve growth factor: developmental and topographical expression in the brain. Proc Natl Acad Sci USA 87:5454-5458.

Escandón E, Chao MV (1990) Identification of high-and low-affinity NGF receptors during development of the chicken central nervous system. Dev Biol 142:293-300.

Escandón E, Burton LE, Szonyi E, Nikolics K (1993) Characterization of neurotrophin receptors by affinity crosslinking. J Neurosci Res 34 : 601-613.

Finlay BL, Slattery M (1983) Local differences in the amount of early cell death in neocortex predict adult local specializations. Science 219 1349-1351.

Garner AS, Large TH (1992) Evidence for kinaseless and alternate 5 terminal forms of trkB and trkC in chick. Soc Neurosci Abstr 18:950.

Garofalo L, Ribeiro-da-Silva A, Cuello AC (1992) Nerve growth factor-induced synaptogenesis and hypertrophy of cortical cholinergic terminals. Proc Natl Acad Sci USA 89:2639-2643.

Grob P, Berlot CH, Bothwell MA (1983) Affinity labeling and partial purification of nerve growth factor receptors from rat pheochromocytoms and human melanoma cells. Proc Natl Acad Sci USA 80: 6819-6823.

Hahm JO, Langdon RB, Sur M (1991) Disruption of retinogeniculate afferent segregation by antagonists to NMDA receptors. Nature 351 : $568-570$.

Halböök F, Ibanez CF, Persson H (1991) Evolutionary studies of the nerve growth factor family reveal a novel member abundantly expressed in Xenopus ovary. Neuron 6:845-858.

Hempstead BL, Schleifer LS, Chao MV (1989) Expression of functional nerve growth factor receptors after gene transfer. Science 243: 373-375.

Hempstead BL, Martin-Zanca D, Kaplan DR, Parada LF, Chao MV (1991) High-affinity NGF binding requires coexpression of the trk proto-oncogene and the low-affinity NGF receptor. Nature 350:678683.

Henderson Z (1991) Is nerve growth factor required for the survival of retinal ganglion cells during development? Brain Res 549:322-326.

Henderson Z, Finlay BL, Wikler KC (1988) Development of ganglion cell topography in ferret retina. J Neurosci 8:1194-1205. 
Hohn A, Leibrock J, Bailey K, Barde Y-A (1990) Identification and characterization of a novel member of the nerve growth factor/brainderived neurotrophic factor family. Nature 344:339-341.

Hosang M, Shooter EM (1985) Molecular characteristics of nerve growth factor receptors on PC12 cells. J Biol Chem 260:655-662.

Jackson CA, Peduzzi JD, Hickey TL (1989) Visual cortex development in the ferret. I. Genesis and migration of visual cortical neurons. J Neurosci 9:1242-1253.

Jing S, Tapley P, Barbacid M (1992) Nerve growth factor mediates signal transduction through trk homodimer receptors. Neuron 9:10671079.

Johnson JE, Barde Y-A, Schwab M, Thoenen H (1986) Brain-derived neurotrophic factor supports the survival of cultured rat retinal ganglion cells. J Neurosci 6:3031-3038.

Johnson JK, Casagrande VA (1993) Prenatal development of axon outgrowth and connectivity in the ferret visual system. Vis Neurosci 10:117-130.

Kaplan DR, Martin-Zanca D, Parada LF (1991) Tyrosine phosphorylation and tyrosine kinase activity of the trk proto-oncogene product induced by NGF. Nature 350:158-160.

Kaplan DR, Matsumoto K, Lucarelli E, Thiele CJ (1993) Induction of trkB by retinoic acid mediates biologic responsiveness to BDNF and differentiation of human neuroblastoma cells. Neuron 11:321331.

Kashles O, Yarden Y, Fischer R, Ullrich A, Schlessinger J (1991) A dominant negative mutation suppresses the function of normal epidermal nerve growth factor receptors by heterodimerization. Mol Cell Biol 11:1454-1463.

Katz LC (1987) Local circuitry of identified projection neurons in cat visual cortex brain slices. J Neurosci 7:1223-1249.

Klein R, Parada LF, Coulier F, Barbacid M (1989) trkB, a novel tyrosine protein kinase receptor expressed during mouse neural development. EMBO J 8:3701-3709.

Klein R, Conway D, Parada LF, Barbacid M (1990a) The trkB tyrosine protein kinase codes for a second neurogenic receptor that lacks the catalytic kinase domain. Cell 61:647-656.

Klein R, Martin-Zanca D, Barbacid M, Parada LF (1990b) Expression of the tyrosine kinase receptor gene trkB is confined to the murine embryonic and adult nervous system. Development 109:845-850.

Klein R, Jing S, Nanduri V, O'Rourke E, Barbacid M (1991a) The trk proto-oncogene encodes a receptor for nerve growth factor. Cell 65:189-197.

Klein R, Nanduri V, Jing S, Lamballe F, Tapley P, Bryant S, CordonCardo C, Jones KR, Reichardt LF, Barbacid M (1991b) The trkB tyrosine protein kinase is a receptor for brain-derived neurotrophic factor and neurotrophin-3. Cell 66:395-403.

Klein R, Lamballe F, Bryant S, Barbacid M (1992) The trkB tyrosine protein kinase is a receptor for neurotrophin-4. Neuron 8:947-956.

Knüsel B, Rabin S, Hefti F, Kaplan DR (1994) Regulated neurotrophin receptor responsiveness during neuronal migration and early differentiation. J Neurosci 14:1542-1554.

Koh S, Higgins GA (1991) Differential regulation of the low-affinity NGF receptor during postnatal development of the rat brain. J Comp Neurol 313:494-508.

Kordower JH, Mufson EJ (1992) Nerve growth factor receptor-immunoreactive neurons within the developing human cortex. J Comp Neurol 323:25-41.

Lamballe F, Klein R, Barbacid M (1991) trkC, a new member of the trk family of tyrosine protein kinases, is a receptor for neurotrophin3. Ccll 66:967-979.

Law MI, Zahs KR, Stryker MP (1988) Organization of primary visual cortex (area 17) in the ferret. J Comp Neurol 278:157-180.

Leibrock J, Lottspeich F, Hohn A, Hofer M, Hengerer B, Masiakowski P, Thoenen H, Barde Y-A (1989) Molecular cloning and expression of brain-derived neurotrophic factor. Nature 341:149-152.

Linden DC, Guillery RW, Cucchiaro J (1981) The dorsal lateral geniculate nucleus of the normal ferret and its postnatal development. J Comp Neurol 203:189-211.

Loeb DM, Maragos J, Martin-Zanca D, Chao MV, Parada LF, Greene LA (1991) The trk proto-oncogene rescues NGF responsiveness in mutant NGF-nonresponsive PC12 cell lines. Cell 66:961-966.

Lohof AM, Ip NY, Poo MM (1993) Potentiation of developing neuromuscular synapses by the neurotrophins NT-3 and BDNF. Nature 363:350-353.

Maffei L, Berardi N, Domenici L, Parisi V, Pizzorusso T (1992) Nerve growth factor (NGF) prevents the shift in ocular dominance distribution of visual cortical neurons in monocularly deprived rats. $\mathrm{J}$ Neurosci 12:4651-4662.

Maisonpierre PC, Belluscio L, Squinto S, Ip NY, Furth ME, Lindsay RM, Yancopoulos, GD (1990) Neurotrophin-3: a neurotrophic factor related to NGF and BDNF. Science 247:1446-1451.

Martin-Zanca D, Oskam R, Mitra G, Copeland T, Barbacid M (1989) Molecular and biochemical characterization of the human trk protooncogene. Mol Cell Biol 9:24-33.

Martin-Zanca D, Barbacid M, Parada LF (1990) Expression of the trk proto-oncogene is restricted to the sensory cranial and spinal ganglia of neural crest origin in mouse development. Genes Dev 4:683-694.

Massague J, Buxser S, Johnson GL, Czech MP (1982) Affinity labeling of nerve growth factor receptor on rat pheochromocytoma (PC12) cells. Biochim Biophys Acta 693:205-212.

McConnell SK (1991) The generation of neuronal diversity in the central nervous system. Annu Rev Neurosci 14:269-300.

Meakin SO, Shooter EM (1991) Molecular investigations on the highaffinity nerve growth factor receptor. Neuron 6:153-163.

Meinecke DL, Rakic P (1993) Low-affinity p75 nerve growth factor receptor expression in the embryonic monkey telencephalon: timing and localization in diverse cellular elements. Neuroscience 54:105116.

Middlemas DS, Lindberg RA, Hunter T (1991) trkB, a neural receptor protein-tyrosine kinase: evidence for a full-length and two truncated receptors. Mol Cell Biol 11:143-153.

O'Leary DDM, Fawcett JW, Cowan WM (1986) Topographic targeting errors in the retinocollicular projection and their elimination by selective ganglion cell death. J Neurosci 6:3692-3705.

Purves D, Snider WD, Voyvodic JT (1988) Trophic regulation of nerve cell morphology and innervation in the autonomic nervous system. Nature 336:123-128.

Radeke MJ, Misko TP, Hsu C, Herzenberg LA, Shooter EM (1987) Gene transfer and molecular cloning of rat nerve growth factor receptor. Nature 325:593-597.

Rickman D, Brecha N, Dawbarn D (1991) Nerve growth factor receptor-immunoreactivity in central visual pathways of the developing rabbit brain. Soc Neurosci Abstr 17:1471.

Rodriguez-Tébar A, Jeffrey PL, Thoenen H, Barde Y-A (1989) The survival of chick retinal ganglion cells in response to brain-derived neurotrophic factor depends on their embryonic age. Dev Biol 136: 296-303.

Rodriguez-Tébar A, Dechant G, Barde Y-A (1990) Binding of brainderived neurotrophic factor to the nerve growth factor receptor. Neuron $4: 487-492$

Kodriguez-'Tébar A, Dechant G, Gotz R, Barde Y-A (1992) Binding of neurotrophin-3 to its neuronal receptors and interactions with nerve growth factor and brain-derived neurotrophic factor. EMBO J 11: 917-922.

Rosenthal A, Goeddel DV, Nguyen T, Lewis M, Shih A, Laramee GR, Nikolics K, Winslow JW (1990) Primary structure and biological activity of a novel human neurotrophic factor. Neuron 5:767-773.

Rosenthal A, Goeddel DV, Nguyen T, Martin E, Burton LE, Shih A, Laramee GR, Wurm F, Mason A, Nikolics K (1991) Primary structure and biological activity of human brain-derived neurotrophic factor. Endocrinology 129:1289-1294

Schatteman G, Biggs L, Lanahan AA, Claude P, Bothwell M (1988) Expression of NGF receptor in the developing and adult primate central nervous system. J Neurosci 8:860-873.

Schneider R, Schweiger M (1991) A novel modular mosaic of cell adhesion motifs in the extracellular domains of the neurogenic trk and trkB tyrosine kinase receptors. Oncogene 6:1807-1811.

Shatz CJ (1983) The prenatal development of the cat's retinogeniculate pathway. J Neurosci 3:482-499.

Shatz CJ (1990) Impulse activity and the patterning of connections during CNS development. Neuron 5:745-756.

Shatz CJ, Ghosh A, McConnell SK, Allendoerfer KL, Friauf E, Antonini A (1990) Pioneer neurons and target selection in cerebral cortical development. Cold Spring Harbor Symp Quant Biol 55:469-480.

Shelton DL, Shooter EM (1988) Production of a polyclonal antiserum recognizing the NGF receptor. Soc Neurosci Abstr 14:826.

Soppet D, Escandón E, Maragos J, Middlemas DS, Reid SW, Blair J, Burton E, Stanton BR, Kaplan DR, Hunter T, Nikolics K, Parada LF (1991) The neurotrophic factors brain-derived neurotrophic fac- 
tor and neurotrophin- 3 are ligands for the trkB tyrosine kinase receptor. Cell 65:895-903.

Squinto SP, Stitt TN, Aldrich TH, Davis S, Bianco SM, Radziejewski C, Glass DJ, Masiakowski P, Furth ME, Valenzuela DM, DiStefano PS, Yancopoulos GD (1991) trkB encodes a functional receptor for brain-derived neurotrophic factor and neurotrophin-3 but not nerve growth factor. Cell 65:885-893.

Sretavan D, Shatz CJ (1984) Prenatal development of individual retinogeniculate axons during the period of segregation. Nature 308 : 845-848.

Thoenen H, Barde Y-A (1980) Physiology of nerve growth factor. Physiol Rev 60:1284-1335.

Tsoulfas P, Soppet D, Escandon E, Tessarollo L, Mendoza-Ramirez J-L, Rosenthal A, Nikolics K, Parada LF (1993) The rat trkC locus encodes multiple neurogenic receptors that exhibit differential response to neurotrophin-3 in PC12 cells. Neuron 10:975-990.

Ueno H, Gunn M, Dell K, Tseng A Jr, Williams L (1992) A truncated form of fibroblast growth factor receptor I inhibits signal transduction by multiple types of fibroblast growth factor receptors. J Biol Chem 267:1470-1476.

Valenzuela DM, Maisonpierre PC, Glass DJ, Rojas E, Nunez L, Kong
Y, Gies DR, Stitt TN, Ip NY, Yancopoulos GD (1993) Alternative forms of trkC with different functional capabilities. Neuron 10:963974.

Wayne DB, Zupan AA, Pearlman AL (1991) An antiserum to the low affinity nerve growth factor receptor labels subplate cells of developing cortex in the mouse and a subset of neurons and glia in tissue culture. Soc Neurosci Abstr 17:1304.

Wheeler EF, Bothwell M (1992) Spatiotemporal patterns of expression of NGF and the low-affinity NGF receptor in rat embryos suggest functional roles in tissue morphogenesis and myogenesis. J Neurosci 12:930-945.

Williams RW, Rakic P (1988) Elimination of neurons from the rhesus monkey's lateral geniculate nucleus during development. J Comp Neurol 272:424-436.

Williams RW, Bastiani MJ, Lia B, Chalupa LA (1986) Growth cones, dying axons, and developmental fluctuations in the fiber population of the cat's optic nerve. J Comp Neurol 246:32-69.

Yan Q, Johnson EM Jr (1988) An immunohistochemical study of the nerve growth factor receptor in developing rats. J Neurosci 8:34813498. 